\title{
ETNOGÊNESE E REELABORAÇÃO DA CULTURA ENTRE OS KRAHÔ-KANELA E OUTROS POVOS INDÍGENAS
}

\author{
VICTOR FERRI MAURO ${ }^{1}$ \\ $U F G D / U F M S$
}

\begin{abstract}
RESUMO: Nos últimos quarenta anos temos assistido no Brasil a intensificação dos processos de etnogênese de grupos indígenas. Populações que por um longo tempo ocultaram as suas identidades têm voltado a afirmar a sua indianidade e passado a lutar pelo reconhecimento de sua condição étnica pelas autoridades de Estado, buscando assegurar o acesso aos direitos específicos previstos pela legislação. A luta desses grupos também visa alcançar condições para que possam reconstruir as suas comunidades, passando a viver com mais dignidade, resgatando a sua autoestima, em busca da cidadania plena. A agência indigenista estatal, no entanto, chegou a negar a "autenticidade" de várias dessas etnias. Por essa razão, a (re)construção dessas identidades perpassa, na maioria das vezes, a elaboração de uma autoimagem sincronizada com as representações estereotipadas que a sociedade brasileira têm do "indio genérico". Esta autoimagem é elaborada na expectativa de adequar-se à representação senso comum que tais comunidades supõem ser um requisito cobrado, sobretudo pelo órgão oficial, para reconhecer a sua condição indígena. A título de exemplo, analisamos mais detidamente o caso emblemático dos índios Krahô-Kanela, do estado do Tocantins.
\end{abstract}

PALAVRAS-CHAVE: Povos indígenas; etnogêneses; identidade; cultura; tradição.

ABSTRACT: Over the past forty years we have seen in Brazil the intensification of the processes of ethnogenesis of indigenous groups. Populations that for a long time concealed their identities, have turned to assert their past and Indianness, fighting for recognition of their status by ethnic state officials, to ensure access to specific rights prescribed by the laws. The struggle of these groups also seeks to achieve conditions to rebuild their communities, going to live with more dignity, restoring their self-esteem, in pursuit of full citizenship. The Indian state agency, however, came to deny the "authenticity" of these various ethnic groups. For this reason, the (re) construction of these identities permeates, in most cases, the development of a self-image synchronized with the stereotypical representations that Brazilian society have of the "generic Indian". This self-image is drawn in the expectation to fit the common sense representation that such communities suppose to be a requirement, particularly by the official body for recognize their indigenous status. For example, we analyze more closely the emblematic case of the Indians Krahô-Kanela, from the state of Tocantins.

KEYWORDS: Indigenous people; ethnogenesis; identity; culture; tradition.

\footnotetext{
${ }^{1}$ Licenciado e bacharel em Ciências Sociais pela Universidade Estadual Paulista, especialista em Turismo e Desenvolvimento Sustentável pela Universidade de Brasília, mestre e doutorando em História pela Universidade Federal da Grande Dourados. Docente do curso de licenciatura em Ciências Sociais da Universidade Federal de Mato Grosso do Sul. E-mail: victorfmauro@yahoo.com.br .
}

Espaço Ameríndio, Porto Alegre, v. 7, n. 1, p. 37-94, jan./jun. 2013. 
VICTOR FERRI MAURO - Etnogênese e reelaboração da cultura entre os krahô-kanela...

\section{Introdução}

Temos observado nas últimas quatro décadas, no Brasil, com maior incidência na região Nordeste, a emergência crescente de grupos que passam a se autodeclarar indígenas. Populações que por muito tempo disfarçaram suas identidades de pouco tempo pra cá voltaram a afirmar a sua indianidade e pleitear o reconhecimento de sua condição étnica pelas autoridades oficiais, o que lhes garantiria o gozo de direitos específicos da condição indígena. Todavia, a agência indigenista estatal, em muitos casos, negou o reconhecimento solicitado, que poderia garantir aos povos indígenas emergentes o acesso aos direitos específicos previstos em lei.

$\mathrm{Na}$ maioria das vezes, essas comunidades acabam se revestindo das representações do "índio genérico" presentes no imaginário senso comum do brasileiro. A (re)construção dessas identidades perpassa, na maioria das vezes, a elaboração de uma autoimagem sincronizada com o retrato estereotipado que a sociedade brasileira idealiza sobre o "ser indígena". Apela-se para isso na expectativa de adequar-se à representação que tais comunidades supõem ser um requisito cobrado pela sociedade envolvente, sobretudo pelo órgão oficial de assistência ao índio, para reconhecer a sua condição indígena. A título de exemplo, analisamos mais detidamente o caso dos índios Krahô-Kanela, que vivem em Lagoa da Confusão, estado do Tocantins, que passaram por uma série de dificuldades e constrangimentos por causa da negativa da FUNAI em reconhecê-los e, consequentemente, assisti-los. Venho realizando pesquisas com este grupo desde 2007, que resultaram até agora na publicação de minha dissertação de mestrado (MAURO, 2011) e de um artigo em parceria com meu orientador (MAURO e EREMITES DE OLIVEIRA, 2010), onde estão presentes parte das ideias que apresento aqui.

\section{Representações estereotipadas do índio na consciência nacional}

No imaginário brasileiro, de modo geral, podemos observar dois 
VICTOR FERRI MAURO - Etnogênese e reelaboração da cultura entre os krahô-kanela...

tipos de representação da imagem do índio que são mais recorrentes. Uma delas é evidentemente negativa e preconceituosa; a outra aparenta ser romântica e apologética do modo de ser indígena. Entretanto, ambas são caracterizações grosseiras, superficiais, distorcidas e simplificadoras da realidade dos povos indígenas. Tornaram-se clichês.

No primeiro tipo, o indígena é apresentado como preguiçoso, indolente, rústico, ignorante e improdutivo. É tido como atrasado no estágio de evolução humana, refratário às forças do progresso e, por isso mesmo, um obstáculo ao desenvolvimento econômico e social. Essa posição é mais comumente encontrada no discurso dos representantes de segmentos que têm interesses opostos aos dos indígenas e cobiçam as suas terras e os recursos existentes nelas, como fazendeiros, garimpeiros, madeireiros, grileiros etc. Essa parece ter sido também a concepção que foi hegemônica no Estado brasileiro até bem pouco tempo, cuja política indigenista visava integrar os chamados "silvícolas" à comunhão nacional.

No segundo tipo de representação, mais facilmente observável entre ativistas e simpatizantes idealistas da causa indígena, os índios são ornados com um misto de características do "bom selvagem" do romantismo de Rousseau e do arquétipo do bom cidadão ocidental, progressista e/ou cristão. Esse segmento considera como características da "autenticidade" cultural indígena a harmonia com a natureza, a vida saudável, o igualitarismo e o altruísmo, o pacifismo, a sabedoria milenar, a vivência espiritual intensa, a arte material e imaterial rica, etc. Os indígenas são enxergados sob uma condição de quase "encantamento" e "pureza", resultantes do isolamento em relação à nossa sociedade, cujo contato consistiria em uma ameaça de contaminação e corrupção dos valores e da cultura tradicional (SAMPAIO, 2006; ARRUDA, 2001). Por esse prisma, se acredita que na medida em que os índios incorporam costumes da população dita "civilizada", vão perdendo a sua essência e se descaracterizando. A miscigenação com não índios também representaria uma ameaça à suposta "pureza racial".

A forma como o indígena mais aparece representado nos meios de comunicação de massa e mesmo em vários livros e cartilhas escolares associa a sua imagem ao passado remoto, a uma condição 
VICTOR FERRI MAURO - Etnogênese e reelaboração da cultura entre os krahô-kanela...

primitiva, próxima ao estado de natureza. Ainda hoje, os índios são idealizados com características semelhantes àquelas que aparecem na iconografia e nos relatos dos cronistas, artistas e exploradores que percorreram o interior do país nos tempos da Colônia e do Império. São vulgarmente pensados como categoria genérica, sem distinção étnica, cultural e linguística, portadores de costumes exóticos e detentores de uma cultura rústica e parada no tempo (PACHECO DE OLIVEIRA, 1999).

Como afirma Moonen,

No Brasil, os índios costumam ser apresentados como seres exóticos de outra "raça" que vivem na selva, andam nus, caçam com arco e flecha, usam estranhos adornos nos lábios e nas orelhas, acreditam em forças sobrenaturais, têm pajés, são liderados por caciques e falam línguas que ninguém entende (MOONEN, 1992, p. 13).

Tais estereótipos nos são ensinados desde os primeiros momentos da vida escolar, através da literatura e de outras formas de conhecimento, sendo intensificados por representações presentes em documentários e reportagens veiculadas na imprensa e na TV, que apresentam a temática indígena de modo espetacularizado, enfatizando o exotismo. Em diversos veículos de comunicação, entretenimento e propaganda, sendo os índios retratados de forma genérica e superficial (MAURO e EREMITES DE OLIVEIRA, 2010).

Em tom de indignação, Fernandes descreve um tipo de atividade que certas escolas brasileiras desenvolvem na data de 19 de abril para comemorar o Dia do Índio:

É muito comum vermos crianças com o rosto pintado com carvão, a cabeça enfeitada com penas de galinha simulando um cocar, e, ainda, vestindo roupas confeccionadas com saco de estopa. Não raro colocam a mão na boca pretendendo imitar os gritos de guerra dos índios.

Lembrando de uma marchinha carnavalesca, repetem uns para os outros: - "índio quer apito" (FERNANDES, 1993, p. 141).

Gallois (2000b) afirma que a maior parte das produções audiovisuais sobre a temática indígena que circulam na grande mídia 
VICTOR FERRI MAURO - Etnogênese e reelaboração da cultura entre os krahô-kanela...

ainda identificam as culturas indígenas com traços exóticos que servem para distanciá-los simbolicamente de nós. Segundo a autora, mesmo os documentários etnográficos preferem retratar os povos portadores de culturas mais contrastantes com a nossa, e quando tratam dos processos de mudança cultural, deixam transparecer um tom de saudosismo com o desaparecimento de técnicas ancestrais, denunciam as "perdas" culturais sofridas por causa da influência externa.

Nascimento (2004) diz que, por serem vistos como portadores de costumes exóticos e desviantes dos padrões da cultura hegemônica, os índios são apreciados muito mais pela curiosidade folclórica que evocam nas pessoas do que respeitados por seus valores.

O fato é que todos aqueles que entendem a identidade indígena como uma condição transitória abalada pelas mudanças culturais, sejam simpatizantes ou não da causa, parecem não se dar conta de que

As culturas são dinâmicas, influenciam-se mutuamente e se constroem também nos contatos com outras culturas, o que não significa absolutamente perda de identidade, e sim, que como a identidade é justamente um elemento construído culturalmente, por sua essência, também é dinâmica (CALEFFI, 2003, p. 195).

Os estereótipos indígenas que mencionamos são representações que compõem o que Bhabha (1998) denomina como discurso colonial, que consiste em uma forma narrativa pela qual os termos "cultura", "história" e "raça" são tomados como signos definidores da diferença na construção ideológica da alteridade. O discurso colonial é utilizado como estratégia de dominação simbólica de gênero, raça, cultura etc. Bhabha considera os estereótipos "uma falsa representação de uma dada realidade" (BHABHA, 1998, p. 117). Eles são constituídos por um conjunto de signos pensados em termos de uma ordem fixa e imutável reproduzidos à exaustão.

A construção dos estereótipos é marcada por processos de subjetivação pelos quais as imagens fixadas para identificar os sujeitos coloniais (colonizador e colonizado) lançam mão de um repertório de signos que marcam posições de poder e resistência, dominação e dependência (BHABHA, 1998).

Através dos estereótipos, o discurso colonial emprega um regime 
VICTOR FERRI MAURO - Etnogênese e reelaboração da cultura entre os krahô-kanela...

de verdade estruturalmente semelhante ao realismo, tornando-se assim apreensível e visível. Tal discurso possui uma intencionalidade política, na medida em que e é formulado pelo dominador com o intuito de justificar a conquista e estabelecer sistemas de administração e instrução sobre o colonizado (BHABHA, 1998).

Os estereótipos negativos, aqueles do primeiro tipo a que nos referimos, "visam a excluir moralmente um grupo do campo de normas e de valores aceitáveis, por uma desumanização que autoriza a expressão do desprezo e do medo e justifica as violências e penas que Ihe infligimos" (JODELET, 2001, p. 64).

\section{A compreensão dos indígenas enquanto categoria racial}

Há muita gente que ainda hoje acredita na existência de raças humanas compostas por conjuntos de indivíduos com traços fenotípicos em comum, que contrastam com os traços de outros grupos "raciais". Sob esse ponto de vista, faria sentido pensar que a população brasileira é multirracial, por ser formada pela convergência - e em parte, pelo amálgama - de "raças" diferentes, como os brancos, os negros, os indígenas e os asiáticos. Talvez as próprias classificações por cor presentes no censo do Instituto Brasileiro de Geografia e Estatística (IBGE) induzam os cidadãos nacionais a pensarem que realmente existem "raças" diferentes, que estariam cada vez mais se diluindo na miscigenação.

No imaginário popular, o índio é representado segundo um fenótipo bem definido: pele morena, estatura média ou baixa, olhos escuros e cabelos pretos e lisos. É difícil conceber um indígena que não tenha essas características. Pensando assim, os índios seriam um tipo específico de "raça". Entretanto, no campo científico, após a década de 1950, são raros os estudos considerados sérios que empregaram o termo "raça" para se referir à diversidade dos tipos humanos encontrada no planeta.

No século XIX e nas primeiras décadas do século seguinte, era vasto o número de estudos da ciência que recorriam à idéia de raça para explicar as diferenças fenotípicas, comportamentais e culturais entre os 
VICTOR FERRI MAURO - Etnogênese e reelaboração da cultura entre os krahô-kanela...

grupos humanos. Muitas dessas abordagens eram de cunho abertamente racista. Hierarquizavam as sociedades e conferiam a elas valores, sentidos e significados diversos, tendo em conta os seus aspectos somáticos, tais como cor da pele e dos olhos, formato do crânio, textura do cabelo, estatura física, volume craniano etc (SCHWARCZ, 1993).

Em meados do século XX, após a Segunda Guerra Mundial, logo em um momento em que as ideologias autoritárias do nazi-fascismo estavam sendo combatidas tenazmente, os estudos em genética humana começavam a revelar que a noção de raça tal como concebida até então por diversos antropólogos, criminalistas e pesquisadores de outras especialidades não fazia o menor sentido em termos de ciência (BARBUJANI, 2007).

Um número significativo de pesquisas realizadas a partir da década de 1970 comprovou que as diferenças fenotípicas entre os mais diversos povos, embora sejam, inegavelmente, o reflexo de adaptações aos climas locais, são bem pouco relevantes naquilo que tange à composição biológica essencial do corpo humano. O homem é uma espécie bastante recente no planeta, vem povoando a Terra há alguns milhares de anos. Deste modo, o tempo evolutivo percorrido por variedades de grupos da espécie homo sapiens em condições de total isolamento não foi suficiente para promover uma diversificação significativa em termos biológicos. Nossa espécie está distante de apresentar uma variedade genética comparável à de espécies efetivamente subdivididas em raças, como os cavalos, os cachorros, e outras. As diferenças nos aspectos do fenótipo são determinadas por uma quantidade muito pouco expressiva de genes, se considerada toda a carga genética do DNA mitocondrial de uma pessoa, e de forma nenhuma influenciam na capacidade intelectual e no comportamento social dos indivíduos.

\section{O entendimento da identidade indígena como condição transitória}

A FUNAl (Fundação Nacional do Índio) até bem pouco tempo apoiava-se no Art. $3^{\circ}$ da Lei $6.001 / 73$, conhecida como "Estatuto do 
VICTOR FERRI MAURO - Etnogênese e reelaboração da cultura entre os krahô-kanela...

Índio" para ter como parâmetro quem deveria ou não ser reconhecido como indígena. Pelo estatuto, o indígena é definido como "todo indivíduo de origem e ascendência pré-colombiana que se identifica e é identificado como pertencente a um grupo étnico cujas características culturais o distinguem da sociedade nacional" (BRASIL, 2008, p. 46). Por comunidade indígena está entendido

Um conjunto de famílias ou comunidades índias, quer vivendo em completo estado de isolamento em relação aos outros setores da comunhão nacional, quer em contatos intermitentes, sem contudo estarem neles integrados (BRASIL, 2008, p. 46).

Destaca-se nestas definições a compreensão de que para ser reconhecido como indígena o indivíduo ou a comunidade precisaria manter características culturais distintas da sociedade nacional e não poderia estar incorporada às relações cotidianas desta.

O tipo de tutela que o Serviço de Proteção aos Índios (SPI) e, a partir de 1967, a Fundação Nacional do Índio (FUNAI) exerceram sobre os indígenas até a promulgação da nova Constituição era profundamente paternalista e antiautonomista. Por essa razão, os gestores das políticas indigenistas não enxergavam sentido na proteção especial de indivíduos e grupos que buscavam maior autodeterminação em relação ao Estado.

Certas autoridades do governo partilhavam da compreensão de que a identidade indígena era um estado transitório e efêmero. Pensava-se que indivíduos e grupos, ao passo em fossem se integrando aos costumes da sociedade envolvente, renunciariam às características culturais tidas como a "essência" de sua identidade. Deste modo, deixariam de ser considerados indígenas, não carecendo mais da tutela do Estado, que Ihes assegurava direitos especiais, como assistência social e jurídica oferecidos pela FUNAl.

Anteriormente à Constituição Federal de 1988, a política indigenista do Estado brasileiro tinha como objetivo declarado a promoção da "integração dos índios à comunhão nacional". Até a década de 1970, muitas pessoas acreditavam que a extinção dos povos indígenas no Brasil não tardaria a acontecer. No período que ficou 
VICTOR FERRI MAURO - Etnogênese e reelaboração da cultura entre os krahô-kanela...

conhecido como "Milagre Econômico", marcado pela forte expansão da economia interna, as frentes colonizadoras se alastravam pelo território nacional, causando sérios impactos para as comunidades indígenas e seus territórios. O governo militar subsidiava a implantação de grandes empreendimentos de infraestrutura, a instalação de indústrias e projetos agropecuários. Os índios eram vistos como entraves ao desenvolvimento. Até então se verificava uma tendência de decréscimo populacional significativo entre os índios por causa, principalmente, da mortandade por contágio de doenças e da precariedade das condições de vida, e também em razão da assimilação cultural de indivíduos e grupos na sociedade envolvente. Até mesmo alguns defensores sinceros da causa indígena, dentre os quais antropólogos, historiadores, ativistas, intelectuais e indigenistas nutriam uma visão pessimista do futuro dos povos indígenas, o que era motivo de lamentação entre eles.

Muitos antropólogos dessa época ainda estavam altamente influenciados por teorias desenvolvidas pela antropologia clássica que percebiam as sociedades indígenas em termos de configurações fixas, tendentes ao equilíbrio interno permanente, refratárias às mudanças, com lógicas, instituições e padrões de comportamento estáveis e, por isso mesmo, sem história. A todo esse conjunto se dava o nome de "cultura tradicional". Acreditava-se que os grupos indígenas estariam fadados a perderem essa cultura tradicional e que, mais cedo ou mais tarde, seriam assimilados na civilização ocidental através do processo de aculturação. Essa perspectiva destituía os índios de sua condição de sujeitos históricos.

No final dos anos 1970 e início dos anos 1980, a cúpula do poder na FUNAI, da qual participavam militares de alta patente, debateu em várias ocasiões o grau de mudanças culturais que poderiam considerar aceitáveis para reconhecer determinados indivíduos ou grupos como indígenas. No ano de 1978, o ministro do interior, Rangel Reis, anunciava a intenção de enviar ao Congresso um anteprojeto de lei prevendo a emancipação de vários grupos indígenas considerados por ele "aculturados". No dia 27 de dezembro de 1976, Reis havia declarado:

Vamos procurar cumprir as metas fixadas pelo presidente Geisel, para que através de um trabalho concentrado entre vários Ministérios, daqui a 10 anos 
VICTOR FERRI MAURO - Etnogênese e reelaboração da cultura entre os krahô-kanela...

possamos reduzir para 20 mil os 220 mil índios existentes no Brasil e daqui a 30 anos, todos eles estarem devidamente integrados na sociedade nacional (REIS apud COMISSÃO PRÓ-INDIO, 1979, p. 11).

Viveiros de Castro explica que:

O problema da época, muito ao contrário de qualquer "emergência", era a submergência das etnias, era o problema das etnias submergentes, daqueles coletivos que estavam seguindo, por força das circunstâncias $[\ldots]$, uma trajetória histórica de afastamento de suas referências indígenas, e de quem, com esse pretexto, o governo queria se livrar: "Esse pessoal não é mais índio, nós lavamos as mãos. Não temos nada a ver com isso. Liberem-se as terras deles para o mercado; deixese eles negociarem sua força de trabalho no mercado" (VIVEIROS DE CASTRO, 2006, p. 42).

Para alguns analistas, o modo como o Estado pretendia integrar os indígenas em nada seria benéfico para eles. Segundo Moonen:

A integração, em última análise, significaria a proletarização do índio, sua transformação em mão-deobra barata e em produtor e consumidor dentro da sociedade nacional capitalista. Ela não beneficiaria o índio, não melhoraria suas condições de vida, antes pelo contrário. O índio seria integrado nas classes mais baixas e miseráveis da população nacional (MOONEN, 1988 , p. 35).

Em razão da pressão contrária do movimento indígena, de ONGs, associações científicas, antropólogos, sertanistas e outros segmentos simpatizantes à causa dos índios, a pretensão do ministro foi abandonada. Porém, no início dos anos 1980, conforme relata Athias (2007), o órgão indigenista criou uma comissão incumbida de elaborar indicadores de identificação indígena a serem aplicados no Brasil a partir de critérios sanguíneos, ou seja, por amostra de DNA. Felizmente, esses critérios absurdos nunca chegaram a ser implementados na prática. De todo modo, ficou claro que a ideia de raça humana, embora já não conservasse muita credibilidade no meio científico naquele momento, ainda permanecia arraigada na mentalidade de dirigentes do indigenismo de Estado.

Espaço Ameríndio, Porto Alegre, v. 7, n. 1, p. 37-94, jan./jun. 2013. 
VICTOR FERRI MAURO - Etnogênese e reelaboração da cultura entre os krahô-kanela...

\section{Ascensão do movimento indígena e emergências étnicas}

A reação ao teor do decreto do ministro do interior que previa a possibilidade da emancipação de grupos indígenas acabou convergindo uma série de profissionais (antropólogos, advogados, jornalistas, religiosos e artistas) em defesa de uma plataforma comum de resistência pró-índio. Lideranças indígenas se projetaram de repente na cena pública, conquistando espaço para se pronunciarem nos meios de comunicação, obtendo a partir daí a simpatia e a adesão de vários segmentos da sociedade civil, embalando protestos que pressionaram o governo, culminando no engavetamento do projeto de emancipação. Foi uma fase heroica do indigenismo, cujos acontecimentos alavancaram a consolidação de organizações dos povos indígenas e de entidades não indígenas de apoio à causa (RAMOS, 1995).

Segundo Viveiros de Castro,

A grita suscitada com o projeto de emancipação resgatou a questão indígena do folclore de massa a que havia sido reduzida. Ela fez com que os próprios índios se dessem conta de que, se eles não tomassem cuidado, iam deixar de ser índios mesmo, e rapidinho. Graças a isso, então e enfim, os índios se tornaram muito mais visíveis como atores e agentes políticos no cenário nacional (VIVEIROS DE CASTRO, 2006, p. 42).

O movimento social indígena passa a atuar de forma mais organizada no cenário nacional a partir da década de 1970 e é fortalecido por outros movimentos políticos que emergem na mesma época e que passam a serem mais incisivos no momento histórico de transição da ditadura militar - em esgotamento - para a abertura democrática no início dos anos 80.

Segundo Nascimento (2004), as pastorais indígenas reavaliaram os seus procedimentos, mudando radicalmente a sua doutrina e os seus métodos de ação com os povos indígenas. A política do assistencialismo e do controle rígido dá lugar à valorização das culturas nativas e à orientação dos indígenas no que concerne aos seus direitos territoriais e à sua autodeterminação. Essas entidades assumiram o desafio de 
VICTOR FERRI MAURO - Etnogênese e reelaboração da cultura entre os krahô-kanela...

trabalhar na consciência do indígena a noção de autonomia e projetar na sociedade não índia uma concepção do índio enquanto sujeito de direitos, que merecia gozar da cidadania e viver com dignidade.

Dentre as principais organizações da sociedade civil de apoio aos povos indígenas que surgiram ainda no período da ditadura, podemos citar a OPAN (Operação Anchieta), criada em 1969 e transformada em organização leiga denominada Operação Amazonas; o CIMI (Conselho Indigenista Missionário), entidade ligada a setores progressistas da Igreja Católica, criado em 1972; o CTI (Centro de Trabalho Indigenista), criado em 1979; a Comissão Pró-Índio, criada em 1978 e o CEDI (Centro Ecumênico de Documentação e Informação), criado em 1974 e composto por segmentos progressistas de várias religiões, dentre as quais a católica, a luterana, a metodista e a anglicana. Essas organizações reforçaram o movimento indígena e deram sustentação para o ressurgimento social de povos que, no dizer de Nascimento, "pareciam adormecidos na consciência de si próprios" (NASCIMENTO, 2004, p. 57).

Uma série de assembleias que congregavam lideranças indígenas de diferentes pontos do Brasil foi promovida por entidades pró-índio com destaque para o CIMI -, no sentido de fortalecer o movimento indígena no plano nacional, articulando a luta em torno de interesses e reivindicações comuns de todos os povos frente ao Estado. Esse fortalecimento influenciou na participação atuante de indígenas e seus apoiadores na formalização de princípios que foram incorporados ao texto da Constituição de 1988.

A nova Carta Magna revertia o paradigma integracionista da política indigenista estatal e enfatizava o direito das populações indígenas de gozarem de proteção à sua forma de vida segundo seus usos, costumes e tradições. Também introduziu um grande avanço no que tange ao reconhecimento e à proteção dos territórios tradicionais e dos recursos naturais presentes neles.

A positividade do momento amenizava o estigma que a identidade indígena carregava até então. Isso favoreceu a intensificação dos processos de etnogênese ${ }^{2}$ de grupos que por um longo tempo foram

\footnotetext{
${ }^{2}$ Utilizo aqui a palavra etnogênese, tal como fez Bartolomé, para designar "o ressurgimento de grupos étnicos considerados extintos, totalmente 'miscigenados' ou 'definitivamente' aculturados e que, de
}

Espaço Ameríndio, Porto Alegre, v. 7, n. 1, p. 37-94, jan./jun. 2013. 
VICTOR FERRI MAURO - Etnogênese e reelaboração da cultura entre os krahô-kanela...

obrigados a disfarçar a sua identidade indígena como estratégia de sobrevivência. Segundo a análise de Viveiros de Castro,

A Constituição de 1988 interrompeu juridicamente (ideologicamente) um projeto secular de desindianização, ao reconhecer que ele não se tinha completado. E foi assim que as comunidades em processo de distanciamento da referência indígena começaram a perceber que voltar a "ser" índio - isto é, voltar a virar índio, retomar o processo incessante de virar índio - podia ser interessante. Converter, reverter, perverter ou subverter o dispositivo de sujeição armado desde a Conquista de modo a torná-lo dispositivo de subjetivação; deixar de sofrer a própria indianidade e passar a gozá-la (VIVEIROS DE CASTRO, 2006, p. 43).

A intensificação do fenômeno das etnogêneses tem sido verificada no Brasil um pouco antes até, a partir da década de 1970, em todas as regiões, mas principalmente no Nordeste. O número de comunidades que se autodeclaram indígenas vem crescendo significativamente a cada ano, e, junto com as demandas por reconhecimento por parte do Estado, quase sempre são apresentadas reivindicações pela cobertura de direitos diferenciados, principalmente no que tange à regularização de territórios que consideram de ocupação tradicional sua. Muitos desses grupos, por um longo tempo, escamotearam as suas identidades étnicas para evitar serem vítimas de discriminações e perseguições, e passaram a assumir publicamente a sua indianidade ${ }^{3}$ a partir do momento que sentiram que o cenário se tornara mais propício e que a opinião pública manifestava maior simpatia pela sua causa.

Luciano (2006) avalia que a ascensão do movimento indígena organizado a partir dos anos 1970 fez com que os povos originários

repente, reaparecem no cenário social, demandando seu reconhecimento e lutando pela obtenção de direitos ou recursos" (BARTOLOMÉ, 2006, p. 39-40). Ampliando um pouco mais essa perspectiva, aplico o conceito de etnogêneses também aos casos de surgimentos de novas identidades, além dos casos de reinvenção de etnias anteriormente existentes.

${ }^{3}$ Ao utilizar o termo "indianidade", alguma vezes pronunciado neste texto, estou pensando o conceito no mesmo sentido em que ele é empregado por Arruti; isto é: "[...] uma determinada forma de ser e de conceber-se 'índio', no sentido genérico do termo, construída na interação com o órgão tutelar, a partir de uma determinada imagem do que deve ser um 'índio'. Assim, a 'indianidade' é uma representação e um tipo de comportamento, gerado pela interação de povos indígenas com os aparelhos de Estado e seus procedimentos estandartizados, que impõem à grande diversidade de culturas e organizações sociais um modelo, que acaba sendo assumido efetivamente por aqueles povos" (ARRUTI, 2006, p. 54).

Espaço Ameríndio, Porto Alegre, v. 7, n. 1, p. 37-94, jan./jun. 2013. 
VICTOR FERRI MAURO - Etnogênese e reelaboração da cultura entre os krahô-kanela...

aceitassem a denominação genérica de índio ou indígena como identidade que une e articula povos nativos de todo o país e, num plano mais amplo, de todo o continente. Assumido com orgulho, o termo índio conquistou um maior valor social também para com uma parcela mais politizada da sociedade brasileira. $O$ referido autor avalia que

O processo de afirmação das identidades étnicas, articulado no plano estratégico pan-indígena por meio da aceitação da denominação genérica de índios ou indígenas, resultou na recuperação da auto-estima dos povos indígenas perdida ao longo dos séculos de dominação e escravidão colonial. O índio de hoje é um índio que se orgulha de ser nativo, de ser originário, de ser portador de civilização própria e de pertencer a uma ancestralidade particular. Este sentimento e esta atitude positiva estão provocando o chamado fenômeno da etnogênese, principalmente no Nordeste. Os povos indígenas, que por força de séculos de repressão colonial escondiam e negavam suas identidades étnicas, agora reivindicam o reconhecimento de suas etnicidades e de suas territorialidades nos marcos do Estado brasileiro (LUCIANO, 2006, p. 33).

No cômputo das estatísticas, as etnogêneses ajudaram a reverter a tendência de declínio demográfico da população indígena brasileira existente até meados do século XX. É claro que essa não foi a única causa responsável. Políticas de saúde, saneamento e assistência social engendradas pelo poder público reduziram a mortalidade infantil e elevaram a expectativa de vida desses grupos, embora não os tenham tirado da pobreza e da condição de dependência externa.

Bartolomé (2006) afirma que em certos casos, as emergências de novas etnias podem derivar indiretamente de políticas públicas específicas de forma não planejada. Grupos indígenas em toda a América Latina estariam recuperando e atualizando antigas filiações étnicas que haviam sido induzidos ou obrigados a renunciar, agora na expectativa de obterem potenciais benefícios coletivos garantidos nas novas legislações, que passam a assegurar direitos antes negados, como o acesso ao território e a programas de assistência econômica e social. A amenização do estigma da filiação nativa também colabora para acentuar o orgulho de quem assume a indianidade. No entanto, esse autor não se reduz a adotar uma perspectiva instrumentalista,

Espaço Ameríndio, Porto Alegre, v. 7, n. 1, p. 37-94, jan./jun. 2013. 
VICTOR FERRI MAURO - Etnogênese e reelaboração da cultura entre os krahô-kanela...

focada apenas nas vantagens estratégicas de se recorrer ao discurso identitário. Em suas próprias palavras, considera que "o fato de que a etnogênese possa servir em determinada conjuntura para obter algum recurso crucial, como a terra, não pressupõe a configuração da coletividade étnica exclusivamente para esse fim" (BARTOLOMÉ, 2006, p. 45). Ele também destaca as pretensões de reconstrução da coletividade étnica através de projetos de sociedade que ambicionam reconstituir vivências e formas de sociabilidade comunitárias anteriormente desintegradas, onde estão fortemente presentes as ideologias, as subjetividades e os afetos. Outra coisa que se busca através do reconhecimento étnico é a própria dignidade do grupo (BARTOLOMÉ, 2006, p. 56). Detalharemos isso mais adiante.

$\mathrm{O}$ autor tem plena consciência de que assumir a identidade indígena, no caso dos povos emergentes, não acarreta apenas benefícios, mas enseja também um pesado ônus, pois,

Recuperar uma identificação estigmatizada pela discriminação social não é um processo pessoal ou social simples, isento de conflitos existenciais. Não se trata de um romantismo nostálgico, do qual só se esperam resultados gratificantes, mas da adoção deliberada de uma condição tradicionalmente subalterna, à qual se pretende imprimir uma nova dignidade. Isto pressupõe uma atitude contestatória e de desafio diante da sociedade majoritária em que se gestou o preconceito (BARTOLOMÉ, 2006, p. 56).

\section{A negação do reconhecimento oficial da identidade}

Várias comunidades indígenas emergentes tiveram seus pleitos negados pelas autoridades do Estado, que lançavam suspeitas sobre a "autenticidade" da condição étnica autoproclamada. O órgão tutor dos índios reagiu às etnogêneses colocando em suspeição a legitimidade da condição indígena desses grupos, desacreditando-os e desdenhando-os em várias situações, como se fossem "falsos índios", meros "caboclos" dissimulando a verdadeira identidade para acessar direitos específicos (MAURO e EREMITES DE OLIVEIRA, 2010).

O tratamento pela denominação genérica de caboclos, nesse 
VICTOR FERRI MAURO - Etnogênese e reelaboração da cultura entre os krahô-kanela...

contexto, se dava em razão de os grupos indígenas não mais apresentarem sinais diacríticos radicalmente contrastantes em relação aos regionais. O termo caboclo, em muitas regiões brasileiras era empregado para designar o indígena supostamente "aculturado" em razão da convivência estreita com a interface regional da sociedade não indígena. Esse rótulo, em outros tempos, acabou sendo interiorizado pelos índios a ponto de se transformar em autoidentificação, sobretudo em contextos conflituosos, que imputavam à denominação indígena uma conotação de inferioridade. Deste modo, os indígenas incorriam em tentativas de apagar sinais de seu estigma (na linguagem, no modo de falar, nas vestes etc.) para dissimular a sua identidade, em um esforço para se mostrarem mais civilizados diante dos olhares alheios.

Porto Alegre (1992/1993) enfatiza que o conceito de caboclo geralmente é utilizado em referência aos "mestiços" de origem indígena e carrega um sentido pejorativo determinado pela população "branca"4 hegemônica. Lima (1999) observa que o termo caboclo é complexo, ambivalente e contém uma carga semântica negativa. Nele estão incluídas dimensões geográficas, raciais e de classe. Identifica-se por meio dele uma coletividade de pessoas de status inferior. A categoria caboclo faz menção à origem rural, à ascendência indígena, ao comportamento rústico e a pouca escolaridade. Esse termo não está associado a um dado grupo étnico ou social, podendo ser designado a todo e qualquer grupo ou pessoa que possua esses aspectos. O seu uso corriqueiro nos induz ao erro de acreditar na existência real de uma população cuja identidade cabocla é autoevidente e pode ser atestada por evidências empíricas (MAURO e EREMITES DE OLIVEIRA, 2010).

$\mathrm{Na}$ região amazônica, até bem pouco tempo, a identidade indígena era um estigma; isto é,

uma marca infame, uma mancha na reputação, um desdouro, uma desonra decorrente de uma opinião sem maior ponderação ou conhecimento dos fatos. [...] a etiqueta que aparece primeiro aos nossos olhos e nos faz desconsiderar todos os elementos da identidade pessoal e social (RIBAS, 2002, p. 91).

\footnotetext{
${ }^{4}$ É bom lembrar que a identidade "branca" não está relacionada aqui a fatores biológicos/raciais e sim relacionada com noções subjetivas de pertencimento social.
}

Espaço Ameríndio, Porto Alegre, v. 7, n. 1, p. 37-94, jan./jun. 2013. 
VICTOR FERRI MAURO - Etnogênese e reelaboração da cultura entre os krahô-kanela...

A preocupação dos indígenas em se livrar do estigma atribuído a sua identidade fica muito clara na seguinte exposição:

\begin{abstract}
Antes da década de 1970, chamar alguém de índio, fosse ele nativo ou não, era uma ofensa. E como a denominação estava associada aos povos nativos, consequentemente as denominações e as autodenominações étnicas eram igualmente indesejáveis. Por isso, muitos índios negavam suas identidades e suas origens, ou melhor, tentavam negar suas origens étnicas, pois na maioria dos casos a negação era uma verdadeira ilusão, uma vez que ninguém consegue esconder aparência física, usos, costumes e modo de vida e de pensamento. A denominação original de caboclo na Amazônia, por exemplo, está fortemente relacionada a essa negação das identidades étnicas dos índios. Foi uma invenção daquelas que não queriam se identificar como índios, mas também não podiam se reconhecer como brancos e negros (pois não pareciam), como se fosse uma identidade de transição de índio (ser inferior ou cultura inferior) para branco (ser civilizado e superior). Neste sentido, o caboclo seria aquele que nega sua origem nativa, mas que por não poder ainda se reconhecer como branco se identificava com o mais próximo possível do branco (LUCIANO, 2006, p. 33).
\end{abstract}

Até mesmo alguns profissionais do indigenismo enxergam os tais caboclos como nativos degradados socialmente, em consequência da conquista colonial e das compulsões negativas impetradas pela sociedade brasileira majoritária. O caboclo seria uma pessoa que, pelo elevado grau de "aculturação", não poderia mais ser aceito como indígena pelas autoridades do Estado, mas que, por outro lado, estaria distante de ser considerado civilizado. Tal forma de pensar desconsidera o fato de que as próprias sociedades indígenas do presente derivam de um violento e desagregador processo histórico colonialista (MAURO e EREMITES DE OLIVEIRA, 2010). Por esta razão, a continuidade entre as identidades indígenas e "caboclas" em muitos casos é má compreendida por esses agentes, como demonstra o fragmento de texto abaixo citado:

No discurso antropológico que concerne às populações indígenas, os caboclos representam tanto os "restos" de sociedades indígenas degradadas, como ameaças imediatas (invasões de terras) às poucas sociedades 
VICTOR FERRI MAURO - Etnogênese e reelaboração da cultura entre os krahô-kanela...

indígenas que transpuseram a catástrofe colonizadora. Nacionalmente, o caboclo representa um projeto incompleto de uma cultura brasileira que rompeu com seus antecedentes europeus, africanos e indígenas (ADAMS, MURRIETA e NEVES, 2006, p. 18).

No Nordeste, o uso do termo caboclo para se referir aos povos indígenas atuais da região também é algo muito frequente. O termo "remanescentes" também foi muitas vezes empregado pelos agentes indigenistas para se referir a uma condição de indígena em avançado processo de "perdas culturais". Seriam aqueles "restos" de sociedades indígenas já bastante "aculturadas".

Arruti explica que

Mesmo no seu uso antropológico, a idéia de "descendência" deposita força na posição do ancestral, mais do que na daquele que dele descende, não estando implícita a transmissão imediata de direitos. Estabelece-se, assim, um compromisso entre uma visão culturalista e outra legal de cultura, de tradição e de identidade: enquanto, de um lado, o culturalismo não admite reconhecer naquela ausência de cultura e tradições puras um valor etnológico próprio, mas apenas relativo ao passado, tomando aqueles grupos em termos de sincretismo e valorizando-os, portanto, não como índios, mas como representantes típicos de uma herança cultural em desaparecimento (ARRUTI, 1997, p. 20-21).

A nomenclatura remanescentes, porém, pode ser apropriada pelos índios emergentes, que passam a lhe dar uma conotação diferente, como aconteceu com vários povos indígenas nordestinos. Ao apontar para os seus vínculos com o passado, tal rótulo resgata para aqueles grupos alguma positividade, ao sugerir a existência de uma historicidade que os conecta com povos cuja existência era reconhecida, justificando assim o seu direito à proteção por parte do Estado. Assim, assumir-se como "remanescente indígena" abre a possibilidade de a comunidade ocupar um novo status na relação com os moradores do entorno, na política do município e da região, diante dos órgãos e políticas do Governo, no imaginário da população brasileira e, inclusive, no seu próprio imaginário. Grupos até então tidos como periféricos ou marginais conquistam a partir daí um novo valor cultural, que tem 
VICTOR FERRI MAURO - Etnogênese e reelaboração da cultura entre os krahô-kanela...

origem em outro quadro de referências, e passam a se enxergar de forma mais digna (ARRUTI, 1997).

A posição de tomar para si a prerrogativa de decidir sobre o reconhecimento da identidade étnica dos povos emergentes continuou sendo reafirmada pela FUNAI até bem recentemente. Geralmente atribuía-se a um estudo antropológico a responsabilidade de investigar se um determinado povo era de fato indígena de pleno direito, fazendo jus à tutela do Estado, ou se se tratava de "farsantes" querendo supostamente enganar as autoridades.

Foi, portanto, designada aos antropólogos a incumbência de, após o levantamento de dados etnográficos, pronunciar-se objetivamente a respeito da etnicidade dos grupos estudados, com poder de discriminação, como se essa objetividade fosse alcançável.

Uma reportagem publicada em uma revista editada pela FUNAI em 2002 comprova que até aquele ano os procedimentos administrativos de reconhecimento étnico estavam em operação e eram considerados indispensáveis. O processo de reconhecimento era descrito como

Um processo longo, nada simples, que exige estudos antropológicos, levantamento histórico e, numa etapa posterior, a identificação das terras ocupadas pelo grupo. As exigências são inúmeras e dependem de prazos, que precisam ser cumpridos, para garantir a eficiência do processo de reconhecimento e evitar futuras contestações (METRE, 2002, p. 5).

A morosidade do processo em si era uma violência contra os grupos indígenas, pois trazia angústia e sofrimento ao longo de anos ou até décadas. Muitas vezes a FUNAI protelou os estudos antropológicos alegando de falta de dotação orçamentária para contratar especialistas.

Alguns burocratas da FUNAI só se convenciam de que a identidade indígena de um dado grupo era "legítima" se o estudo antropológico "comprovasse" a existência de uma continuidade histórica deste com ancestrais de origem pré-colombiana. Supunha-se que essa comprovação podia ser obtida por meio da constatação da sobrevivência de traços culturais distintivos, como a língua ou palavras, danças, canto, grafismo, mitos, crenças, entre outros.

A expectativa de obter dos antropólogos um parecer conclusivo 
VICTOR FERRI MAURO - Etnogênese e reelaboração da cultura entre os krahô-kanela...

sobre a identidade étnica de determinados povos estava presente também nas colaborações desses profissionais, solicitadas com frequência pelo poder judiciário a partir de meados da década de 1980 . Segundo Pacheco de Oliveira (2002), juízes, procuradores e advogados, doutrinados na tradição positivista do direito, aguardavam respostas precisas dos antropólogos sobre questões como essa da identidade, que são muito complexas do ponto de vista da antropologia. O trabalho de levantamento de informações que o antropólogo chamaria de "pesquisa" é nomeado pelos operadores do direito como "perícia", que resulta na elaboração de um "laudo", o qual espera-se que apresente um alto patamar de exatidão técnico-científica.

O ideal seria se todos compreendessem que a intervenção dos antropólogos em processos judiciais e administrativos é uma competência delicada que se exerce em meio a pressões e negociações que envolvem mediadores sociais diversos, como órgãos governamentais, entidades da sociedade civil, associações científicas, universidades, indígenas e interesses privados. Ao contrário disso, costuma-se depositar sobre esse trabalho de antropologia aplicada a esperança de que ele irá revelar um saber de estado cristalizado. Nessa perspectiva, o autor aponta que

Tal como os estudiosos da natureza são capazes de produzir, pela morfologia de animais e plantas, a identificação e a classificação de um exemplar do mundo natural, também o antropólogo deveria ser um especialista capaz de identificar e classificar, pelas formas culturais adotadas, os homens concretos dentro das unidades sociais a que pertenceriam (PACHECO DE OLIVEIRA, 2002, p. 259).

Entretanto, o trabalho se realiza de uma forma muito diferente daquela preconizada por tais expectativas, por uma simples razão:

As formas culturais não revelam a mesma homogeneidade e regularidade que a transmissão genética, e as unidades sociais não são claramente recortadas, descontínuas e permanentes como gêneros e espécies naturais. $E$, principalmente, as unidades sociais mudam com uma velocidade e com uma radicalidade sem precedentes no âmbito do processo da evolução natural. As unidades sociais abandonam 
VICTOR FERRI MAURO - Etnogênese e reelaboração da cultura entre os krahô-kanela...

velhas formas culturais, recebem (e reelaboram) algumas de outras sociedades, e ainda criam formas novas e distintas (PACHECO DE OLIVEIRA, 2002, p. 259).

\section{Identidades étnicas como tipos organizacionais}

Em um livro publicado ineditamente no ano de 1969, o antropólogo norueguês Fredrik Barth sistematizou a concepção de identidade étnica enquanto tipos organizacionais, e não mais como de coletividades sociais que comungam necessariamente de um conjunto de traços culturais peculiares. De acordo com Mauro e Eremites de Oliveira:

Embora Barth admitisse que a cultura fosse um componente importante da etnicidade, considerava um equívoco tê-la como condição primordial para a sua definição, pois, se, por um lado, em nenhuma identidade étnica os conteúdos culturais específicos estão completamente ausentes, por outro, essas identidades também não podem ser tomadas como expressão de uma cultura pré-formatada e imutável (MAURO e EREMITES DE OLIVEIRA, 2010, p. 122).

Suas pesquisas comprovam que identidades diversas podem existir inclusive em cenários sociais que aparentam grande homogeneidade cultural. $\mathrm{O}$ autor sugere que o investigador, ao invés de enfocar o modo em que os traços culturais estão distribuídos, deve tentar compreender a maneira como a diversidade étnica é articulada socialmente e como ela se mantém apesar das mudanças culturais que acontecem.

Barth tem clareza de que a diversidade étnica não está relacionada ao isolamento geográfico e social. Muito pelo contrário, a convivência constante com outros povos reforça a consciência da identidade e realça os limites ou as fronteiras étnicas e o contraste com o modo de ser de grupos distintos. Na realidade, o contato interétnico deixa mais em evidência as particularidades de cada cultura.

Para o antropólogo escandinavo, o processo de interação revigora a consciência e a significação das identidades étnicas dos grupos em 
VICTOR FERRI MAURO - Etnogênese e reelaboração da cultura entre os krahô-kanela...

contato, ao invés de conduzir as sociedades dominadas no sentido da assimilação pelas dominantes.

As etnias, enquanto tipos organizacionais, estabelecem sua identidade através da definição de fronteiras simbólicas, representadas através de categorias ideológicas que demarcam o espaço de pertencimento e de exclusão. Nesses termos,

A etnicidade é sempre forjada em uma relação dialética que contrapõe aqueles que estão dentro com aqueles que estão fora do grupo étnico. A existência dos grupos étnicos depende da manutenção de suas fronteiras, que prescinde das trocas entre os grupos e de toda uma gama de proscrições e prescrições que normatizam suas interações (MAURO e EREMITES DE OLIVEIRA, 2010, p. 123).

As especificidades culturais, quando manifestadas em público, adquirem maior visibilidade, o que é importante, porque a legitimação da identidade também depende do reconhecimento daqueles que estão do lado de fora das fronteiras do grupo. As identidades só adquirem expressividade se puderem formar uma representação significante para o Outro. Os limites simbólicos da fronteira étnica são constantemente negociados. Sua circunscrição depende simultaneamente de definições endógenas (fator subjetivo) e exógenas (fator intersubjetivo) que nunca são exatamente congruentes. A dicotomia entre integrantes e não membros dos grupos é o que assegura a manutenção da fronteira. Ela pode persistir ainda que ocorram transformações nas características dos integrantes dos grupos em contato e nos elementos culturais que delineiam suas diferenças. A diminuição das diferenças culturais entre as etnias não anula obrigatoriamente a relevância dos limites simbólicos usados para distinguí-las (BARTH, 1998).

De modo geral, mesmo dentro do próprio grupo, as definições de pertença étnica nunca são consensuais e sempre estão sujeitas à contestação e redefinição por parte de segmentos internos. Ainda que os traços diferenciadores utilizados na delimitação das fronteiras étnicas sejam manipuláveis, ou seja, suscetíveis a distorções e reinterpretações, eles costumam ser anunciados como atributos naturais e imutáveis, herdados de uma origem comum; isto é, ocorrem processos conscientes de reificação da cultura (POUTIGNAT e STREIFF-FENART, 
VICTOR FERRI MAURO - Etnogênese e reelaboração da cultura entre os krahô-kanela...

1998).

Os grupos étnicos se preocupam constantemente com a construção e redefinição da sua autoimagem porque o processo de demarcação das fronteiras identitárias valoriza esse fundamento. Os traços culturais utilizados são, de preferência, aqueles capazes de estabelecer um maior contraste na relação com os "de fora". Esses aspectos são revestidos de valoração emblemática e ganham um significado de atributo essencial. Porém, sabemos que eles não são tão fixos, pois alterações neles ou nos significados que eles expressam estão sujeitas a acontecer em contextos variados (BARTH, 1998).

Pacheco de Oliveira (2002) esclarece que um grupo dominado pode se organizar de variadas formas conforme o contexto situacional. De acordo com o autor,

Muitas vezes, um grupo dominado não é mantido como uma unidade isolada, mas é incorporado a outras populações (igualmente dominadas ou, inversamente, frações da população dominante), sendo dividido, subdividido e somado a outras unidades de diferentes tipos (PACHECO DE OLIVEIRA, 2002, p. 261).

No Brasil, Roberto Cardoso de Oliveira foi o primeiro a aplicar as idéias de Barth para interpretar a realidade das identificações étnicas indígenas, ainda na década de 1970. Outros se sucederam a ele nos anos 80, como Manuela Carneiro da Cunha (1986) e Carlos Rodrigues Brandão (1986). As contribuições desses autores foram muito importantes para fundamentar antropologicamente os direitos dos povos emergentes. A partir da década de 1990, muitos antropólogos brasileiros passaram a se dedicar aos estudos de emergências étnicas indígenas, principalmente na região Nordeste, utilizado como referência as contribuições de Barth.

A operacionalidade da teoria da identidade relacional repercutiu no texto da Convenção $n^{\circ} 169$ da Organização Internacional do Trabalho (OIT), de 19895, e na Declaração das Nações Unidas sobre o Direito dos Povos Indígenas, de 2006. Por força das inovações incorporadas nos marcos legais, a FUNAI se viu obrigada a rever os seus procedimentos de reconhecimento étnico, mas não sem resistência por parte de alguns

\footnotetext{
${ }^{5}$ Ratificada pelo governo brasileiro por meio do Decreto $\mathrm{N}^{\circ}$ 5.051, de 19 de abril de 2004.
} 
VICTOR FERRI MAURO - Etnogênese e reelaboração da cultura entre os krahô-kanela...

dirigentes e funcionários desta instituição. A partir disso, representantes de grupos indígenas das mais diversas regiões do país se uniram em torno da reivindicação de direitos comuns atinentes ao status jurídico de "índio", suplantando os processos de identificação negativa ou ocultação de sua identidade étnica (PACHECO DE OLIVEIRA, 1999).

Em 2002, o Congresso Nacional ratificou a Convenção 169 da OIT, através do Decreto Legislativo $n^{\circ} 143$. Na data de 29 de maio de 2003, o então presidente da FUNAI, Eduardo Aguiar de Almeida, expediu o Memorando $\mathrm{n}^{\circ}$. 109/PRES/03 ao diretor de assuntos fundiários, comunicando a nova determinação do órgão quanto à política de reconhecimento étnico de populações indígenas:

Pelo presente, informamos à Vossa Senhoria que revimos o procedimento de solicitar laudo antropológico como subsídio a uma resposta desta Fundação às demandas por reconhecimento oficial, dos diversos grupos em situação de emergência étnica. A partir de agora estamos acatando o que preconiza a Convenção no 169 da OIT, que recomenda a auto-identificação como critério fundamental para o reconhecimento da identidade étnica de um grupo (ALMEIDA apud FUNAI, 2003, Memorando n. 109/PRES/03).

No mesmo documento, Almeida informava que, daquele momento em diante, todos os grupos que reivindicavam reconhecimento de sua identidade pela FUNAl seriam considerados sujeitos de direito das políticas públicas voltadas para os povos indígenas brasileiros.

Pouco tempo depois, em setembro de 2003, o antropólogo Mércio Pereira Gomes tomava posse como presidente da FUNAl, substituindo Eduardo Almeida. Em relação ao seu predecessor, Mércio interpretava de modo diverso o que a legislação vigente no Brasil dizia a respeito da identidade dos povos indígenas. Em uma entrevista concedida a integrantes da ONG Instituto Socioambiental, disse o seguinte:

Do ponto de vista da legislação brasileira, seja a Constituição, seja o Estatuto do Índio ou a Convenção 169, é preciso preencher algumas condições sociais e culturais para que ressurgidos sejam reconhecidos como índios. Uma delas é serem reconhecidos pelos "outros" como diferentes; outra é serem, de algum modo, descendentes de culturas indígenas e, ao final, terem consciência de que são índios. Em muitos casos, 
VICTOR FERRI MAURO - Etnogênese e reelaboração da cultura entre os krahô-kanela...

querem começar o processo por este último aspecto. A questão dos ressurgidos está cada vez mais se parecendo com a questão de cotas para minorias. Há controvérsias grandes, e o encaminhamento terminará sendo político (GOMES, 2006, p. 112).

Em uma reunião da Comissão Temporária Externa do Senado Federal, que aconteceu em 16 de junho de 2004, Mércio destacou que, na sua concepção, o reconhecimento oficial de povos indígenas deveria considerar pelo menos três condições indispensáveis, dispostas na conceituação do Estatuto do Índio (Lei $n^{\circ} 6.001 / 73$ ): $1^{\circ}$ ) os povos devem se autoidentificar como indígenas; $2^{\circ}$ ) devem manter "tradições de índios" e $3^{\circ}$ ) devem ter a sua identidade indígena reconhecida por não índios. Na ocasião, ele comentou que, de modo contrário ao que muitos interpretavam a partir da Convenção $\mathrm{n}^{\circ} 169$ da OIT, a autodeclaração não era condição bastante para o reconhecimento oficial de povos indígenas.

Outra declaração de Gomes na mesma ocasião foi a seguinte:

Ser índio no Brasil não é ter sangue exclusivamente nem unicamente, mas ter tradição, ser etnicamente constituído, senão, teríamos de acordo com as genéticas brasileiras cerca de $30 \%$ da população de sangue indígena, e ser índio é ser cultural, é ter um sentimento, seja de coletividade, seja de relação com o passado, seja de oposição cultural, seja de complementaridade (BRASIL, 2004).

A julgar pela declaração supracitada, Gomes sugere que partilhava do entendimento de que a identidade indígena depende, necessariamente, da manutenção de vínculos históricos e culturais com o passado e do contraste com a cultura nacional.

O posicionamento de Mércio Gomes sobre o reconhecimento dos povos emergentes era respaldado pela interpretação que o procuradorgeral da FUNAI, Luiz Fernando Villares e Silva, fazia da legislação em vigor. Na data de 05/01/2006, o procurador encaminhou ao presidente do órgão um ofício no qual emitia um parecer jurídico interpretando que a Convenção $\mathrm{N}^{\circ}$. 169 da OIT coadunava-se com o Artigo $3^{\circ}$ da Lei $\mathrm{n}^{\circ}$. $6.001 / 73$, ao invés de torná-lo sem efeito. Dessa forma, a autoidentificação, no plano legal, tornara-se um critério fundamental 
VICTOR FERRI MAURO - Etnogênese e reelaboração da cultura entre os krahô-kanela...

para o reconhecimento oficial da identidade indígena, mas não o único necessário. Haveria de se considerar também "a identificação pela comunidade e a conservação de determinadas características culturais e institucionais" (OFÍCIO N 10/PGF-PG/FUNAl/07, 2006, p. 5).

Pacheco de Oliveira (2002) comenta que a caracterização contida no artigo $3^{\circ}$ da Lei 6.001 , de que índio é quem se considera como tal e assim é considerado pela sociedade envolvente, em muitos casos é impraticável, pois,

Se uma identificação étnica corresponde a um ato classificatório praticado por um sujeito no interior de um contexto situacional, não faz sentido que as autoclassificações e as classificações por outrem devam necessariamente coincidir (PACHECO DE OLIVEIRA, 2002, p. 261).

No início de 2007 o também antropólogo Márcio Meira assumiu a presidência da FUNAI no lugar de Mércio Gomes. Meira retomou a política de reconhecimento étnico a partir da autodeclaração, como demonstra o trecho de um documento encaminhado ao Presidente da Comissão de Direitos Humanos do Senado:

[...] firmamos o entendimento de que não compete a esta Fundação Nacional do Índio, e em particular, a Diretoria de Assuntos Fundiários questionar a identidade étnica de qualquer comunidade que se autoidentifique e é identificada como indígena, sob pena de ferir o disposto no Decreto $n^{\circ} 5051$, de 19.04.04, que ratificou a Convenção 169 da OIT, garantindo o direito dos Povos Indígenas ao seu auto-reconhecimento étnico (OFÍ́CIO n० 215/DAF/PRES, de 28 de setembro de 2007, n./p.).

Em 13 de setembro de 2007, a Declaração das Nações Unidas sobre o Direito dos Povos Indígenas foi adotada pela Assembleia Geral da ONU. A referida Declaração tratou de esclarecer, no seu Artigo 33, de forma categórica que: "Os povos indígenas têm o direito de determinar sua própria identidade ou composição conforme seus costumes e tradições".

Havemos de concordar, então, com Viveiros de Castro em sua afirmação incisiva de que "Não cabe ao antropólogo definir quem é 
VICTOR FERRI MAURO - Etnogênese e reelaboração da cultura entre os krahô-kanela...

índio, cabe ao antropólogo criar condições teóricas e políticas para permitir que as comunidades interessadas articulem sua indianidade" (VIVEIROS DE CASTRO, 2006, p. 49). Não devemos perder de vista a importância do ensinamento de Pacheco de Oliveira, quando ele fala que

[...] as definições de status jurídico de um grupo étnico como "comunidade" ou "povo indígena" não devem ficar atreladas a uma incerta e disputada materialização de representações genéricas sobre "o índio", mas muitas vezes verificada em situações radicalmente distintas daquelas supostas pelo mito da primitividade. Nesse sentido, o trabalho do antropólogo deve evitar contemporizações, explicitando que considera e reconhece como sociedade indígena toda aquela coletividade que por suas categorias e circuitos de interação se distingue da sociedade nacional, e se reivindica como "indígena", (isto é, descendente - não importa se em termos genealógicos, históricos ou simbólicos - de uma população de origem précolombiana) (PACHECO DE OLIVEIRA, 2002, p. 264).

Nesse mesmo sentido, Teófilo da Silva, alega que:

Tampouco cabe à FUNAI realizar tais "identificações étnicas". Aos aparelhos indigenistas do Estado [...] cabe apenas o papel de solicitar e viabilizar (ou, no mínimo, não inviabilizar) estudos etnográficos, pesquisas de campo, pesquisas bibliográficas e históricas que informem e subsidiem as ações e decisões políticas em prol da proteção dos direitos indígenas, em particular o direito de pessoas e grupos de se auto-afirmar, na qualidade de sujeitos históricos que são, como indígenas autônomos (TEÓFILO DA SILVA, 2005, p. 121-122).

Parece que o problema voltou à baila nos últimos tempos, pois o Ministério Público Federal, de 2008 para cá, engendrou iniciativas em defesa de comunidades indígenas que alegavam ter a sua identidade não reconhecida pela FUNAI. Um exemplo que podemos mencionar é o do povo Maraguá, do estado do Amazonas, cuja denúncia motivou a instauração de um inquérito civil público para apurar os fatos (MINISTÉRIO PÚBLICO FEDERAL, 2011 ). 
VICTOR FERRI MAURO - Etnogênese e reelaboração da cultura entre os krahô-kanela...

\section{Consequências da intervenção das agências indigenistas}

O antropólogo Rinaldo Arruda (2001) reconhece que, nas décadas de 1970 e 1980, os projetos da FUNAl e do governo federal, de maneira geral, que pretendiam emancipar povos indígenas só não se concretizaram porque as próprias comunidades e suas organizações, as entidades indigenistas da sociedade civil e outros apoiadores da causa indígena se posicionaram firmemente contra. Contudo, para este mesmo autor,

As lutas indígenas e pró-indígenas, porém, ainda que tenham sido e sejam fundamentais para criar e manter um espaço de legitimidade para as sociedades nativas, ocorrem nos limites de um campo social e simbólico hegemonicamente definidos por uma ideologia e prática ainda colonialistas. Essa hegemonia tem implicado um processo permanente de "apagamento" das especificidades tribais e de seu "encaixe" em estereótipos produzidos pelos interesses e perspectivas dos agentes que constituem o campo social indigenista, produzindo sentidos-suporte de perspectivas contraditórias no imaginário nacional, base de legitimação das políticas sociais, entre elas a indígena. Isto é, as lutas em torno da questão indígena processam-se tendo como eixo simbólico uma disputa de legitimação de uma imagem do "índio", que sirva melhor de argumento à luta de posições entre os componentes desse campo. Nesse âmbito, ocorre uma permanente reelaboração de sua auto-imagem como objeto-pretexto de variados interesses e perspectivas, que espelham as contradições e os grupos em conflito de nossa sociedade (ARRUDA, 2001, p. 46-47).

Atualmente, a palavra "inclusão" está na ordem do dia no discurso político de partidos dos mais variados matizes ideológicos. A proposta da inclusão social das minorias tem conquistado boa receptividade entre os cidadãos comuns, motivando assim a apropriação desse termo pelo discurso dos governantes. Porém, quando se fala em grupos étnicos diferenciados, é preciso redobrar o cuidado ao analisar qual é o modelo de inclusão que se propõe e se este contempla as suas necessidades e aspirações específicas. Em determinados contextos em que o poder público tem uma preocupação acentuada em demonstrar a valorização 
VICTOR FERRI MAURO - Etnogênese e reelaboração da cultura entre os krahô-kanela...

política das minorias, através da promoção da cidadania por meio da concessão de direitos, paradoxalmente, se promove políticas redutoras das especificidades culturais, que forçam a homogeneização dos particularismos.

Não se pode ignorar que a interação com agentes e entidades do campo do indigenismo, que fazem a intermediação das suas reivindicações, desempenha um papel muito importante na formulação da identidade visual que os indígenas passam a ostentar. Segundo Arruda,

A atuação dos indigenistas, missionários e até dos antropólogos tende a obedecer à lógica de interesses objetivos, de ordem institucional e política, nascidos dos confrontos e alianças que se estabelecem no campo de intermediação. Cada uma das agências participantes desse campo social é guiada por uma ótica específica, ancorada numa imagem do índio que se coaduna com uma perspectiva, ainda que não explícita, de uma humanidade idealizada. Parece mesmo haver um laivo messiânico na atuação indigenista que projeta na figura do índio o exemplo ou o instrumento de sua realização (ARRUDA, 2001, p. 52).

O autor intensifica as suas críticas ao dizer que "as agências de intermediação tendem a atuar no sentido de se tornarem indispensáveis, concentrando o poder de acesso a certos recursos, que legitimam a necessidade de sua presença [no trabalho com as comunidades indígenas]" (ARRUDA, 2001, p. 53); e ainda é mais contundente ao afirmar que "muitas vezes os índios são usados como massa de manobra e induzidos por promessas paternalistas, principalmente por parte de algumas agências estatais" (ARRUDA, 2001, p. 53).

Com a emergência das preocupações ambientalistas no mundo nas últimas décadas, nos parece que a imagem do índio "bom selvagem", ecologista por excelência, vivendo em harmonia com a natureza, tem sido revestida de uma carga semântica positiva muito forte, que ajuda na hora de conseguir financiamento de governos e Organizações Não Governamentais para projetos que tenham em vista a conservação ambiental e manutenção das culturas na sua forma "tradicional". A antropóloga Dominique Gallois, na virada do milênio, afirmava que:

Espaço Ameríndio, Porto Alegre, v. 7, n. 1, p. 37-94, jan./jun. 2013. 
VICTOR FERRI MAURO - Etnogênese e reelaboração da cultura entre os krahô-kanela...

Hoje, os indicadores utilizados para avaliar a situação dos povos indígenas no país estão se alterando com a popularização da temática "ecológica", que valoriza e se apropria de elementos genéricos da "cultura indígena", que passam a ser dotados de altíssimo valor simbólico. Com isso, os grupos indígenas que não exibem marcas de indianidade podem ser depreciados: grupos com pouca visibilidade, ou que aparentam sinais de "aculturação", tendem a ser desfavorecidos no jogo das suas relações com o estado, inclusive em termos de apoio financeiro. Nunca se mobilizou tantas verbas em favor de programas de "resgate" ou de "fortalecimento" cultural, programas esses que tem muitas vezes entrado em choque com as expectativas dos próprios índios, interessados em benefícios menos "tradicionais" e mais adequados a seus anseios de alcançar igualdade de acesso a bens, serviços e conhecimentos, valorizados pela população em seu entorno e que chegam a lhe ser negados porque são índios. A espiral de preconceitos contida na teoria do grande divisor entre eles e nós, continua contrária aos anseios de comunicação e igualdade dos índios: se antes eram "selvagens" a civilizar, hoje devem ocultar suas marcas da "civilização" para receber apoio enquanto índios (GALLOIS, 2000a, p. 10).

$\mathrm{Na}$ percepção da mesma pesquisadora, cada vez mais, as aspirações de futuro que muitos indígenas postulam hoje em dia têm como intenção se apropriar de formas e conteúdos culturais da sociedade mais abrangente para projetar o seu desenvolvimento, mas nem sempre isso é considerado pelos planejadores e gestores das ações voltadas ao atendimento dessas populações (GALLOIS, 2000a).

São muitos os indígenas que desejam hoje viver nas cidades, cursarem universidade, terem empregos bem remunerados e adquirirem bens de consumo valorizados no mundo capitalista. As tecnologias e saberes de nossa sociedade exercem fascínio sobre as populações indígenas. Segundo Gallois (2000b), ao invés de isso ser tratado como ameaças que estariam pairando sobre "técnicas tradicionais" na iminência de se extinguirem, poderia ser abordado como demandas e alternativas legítimas que os próprios índios apresentam e que, ao serem incorporadas à cultura própria, são adaptadas e ressignificadas através de processos criativos.

Espaço Ameríndio, Porto Alegre, v. 7, n. 1, p. 37-94, jan./jun. 2013. 
VICTOR FERRI MAURO - Etnogênese e reelaboração da cultura entre os krahô-kanela...

Alcida Ramos (1995) denuncia que muitas ONGs indigenistas, para justificar a sua própria existência e a necessidade da continuidade do trabalho que desempenham, criam um modelo ideal de índio, que ela chama de índio "hiper-real". Este seria supostamente o "índio de verdade", repleto de virtudes, protótipo acomodado aos interesses da organização burocrática e que toma o lugar da experiência real vivida com os índios. O princípio norteador das ações e dos projetos que essas organizações desenvolvem para captar recursos é a defesa dos direitos dos índios, enquanto povos subjugados, vítimas indefesas das contingências históricas. Dentre os serviços mais comuns que essas entidades prestam aos índios estão: "preparar e encaminhar documentos, promover lobbies com parlamentares, captar recursos para projetos comunitários, denunciar injustiças ou deslanchar campanhas de informação no exterior" (RAMOS, 1995, s./p.).

Gallois expõe que

A prática comum dessas organizações [...] consiste em manter articulações divergentes, mas comparecer juntas em momentos estratégicos, como o das comemorações do "Dia do Índio", para afirmar-se enquanto representantes "legítimas" das populações indígenas da região, angariando fundos e apoios dos mais diversos para fortalecer a ocupação de espaços indispensáveis à visibilidade dos índios, na região e em todo o país (GALLOIS, 2000a, p. 6).

Sobre a relação das ONGs para com os índios, Ramos destaca de maneira crítica uma questão muito interessante:

As entidades de apoio ao índio só existem porque os índios são esbulhados e não têm (ou não tinham, até há pouco tempo) acesso a canais competentes dentro do aparelho de Estado para ventilar suas reivindicações. Logo, as entidades dependem dos índios para sobreviver. Mas - e aí é que vem o paradoxo que inibe uma cooperação orgânica - a máquina burocrática das entidades é alimentada com recursos de agências que mantêm padrões éticos próprios de uma moralidade ocidental; por sua vez, esses padrões instilam-se nas entidades, reclamando que se faça a assepsia da alteridade indígena como contrapartida da colaboração: não é com o índio real que se colabora, mas com o índio-modelo. As entidades dependem dos 
VICTOR FERRI MAURO - Etnogênese e reelaboração da cultura entre os krahô-kanela...

índios, mas dos índios criados por elas (RAMOS, 1995, s./p.).

Para atender ao propósito institucional, os índios muitas vezes parecem ser tratados como uma matéria-prima moldável à ética dos direitos humanos e à impessoalidade da prática burocrática. Porém, no cotidiano dessa relação, esse índio vai se tornando cada vez mais incompreensível para a racionalidade do "escritório" indigenista, que não se abre para um diálogo intercultural mais profundo. Ao se comportarem de um modo que aparentemente transgride essa ética mencionada, como o engajamento em atividades capitalistas de exploração dos recursos naturais de suas terras, os índios são julgados como se desonrassem as entidades que os ajudam, mesmo que a motivação da ação transgressora atenda aos interesses imediatos de seu próprio povo. Segundo Arruda,

O fato de que os povos indígenas não se conformam exatamente a estes modelos idealizados, faz com que os índios efetivamente existentes sejam vistos com desdém, irritação e uma ponta de acusação, algumas vezes até mesmo por seus próprios defensores. Isto é, sejam vistos como "não índios", os índios "descaracterizados", "deculturados", "vendidos", a ponto de não merecerem o esforço que se faz por eles (ARRUDA, 2001, p. 48).

Em situações desse tipo, os indígenas acabam sendo utilizados, acima de tudo, como instrumento de trabalho por ativistas que assumem o papel de defensores da causa sem ter qualquer intimidade existencial ou intelectual com os sujeitos alvo de suas ações. A colaboração entre índios e brancos raramente acontece em condição de simetria.

Diante desse paradoxo, Alcida Ramos vê apenas uma solução viável para escapar da armadilha do simulacro:

Uma vez que a interdependência funcional que caracteriza a organicidade pressupõe a interação de elementos diferentes, mas da mesma ordem, seria necessário abdicar do índio hiper-real e associar-se ao índio real, ou então abdicar de si mesmo como indigenista real e criar o indigenista hiper-real. Nesta última hipótese, teríamos a consagração do simulacro,

Espaço Ameríndio, Porto Alegre, v. 7, n. 1, p. 37-94, jan./jun. 2013. 
VICTOR FERRI MAURO - Etnogênese e reelaboração da cultura entre os krahô-kanela...

ou seja, o simulacro do simulacro: o que se fizesse nessa esfera não teria absolutamente mais nada a ver com o que acontece no mundo dos eventos reais (RAMOS, 1995, s./p.).

Gallois tem razão ao dizer que os índios "têm acessado cada vez mais amplamente imagens e discursos que produzimos a seu respeito, dos quais eles se apropriam como objetos de reflexão" (GALLOIS, 2000b, p .1). Arruda percebe que

Como forma necessária de comunicação com a sociedade nacional [os índios] são forçados ao uso do discurso cultural dominante, ancorando-o simultaneamente em símbolos tradicionais, numa estratégia indispensável para definir diacrítica e politicamente seu lugar e prerrogativas no sistema que os engloba e do qual fazem parte (ARRUDA, 2001, p. 49).

O estreitamento do relacionamento de lideranças indígenas com as agências indigenistas acaba, em grande parte dos casos, afetando o próprio jogo de forças da política interna dessas comunidades. Arruda (2001) nos conta que muitas dessas lideranças passam a viajar com frequência para fora da área indígena, onde estabelecem relações com representantes indígenas de outros grupos que transitam constantemente nas grandes cidades, se hospedam em hotéis, usufruem do conforto urbano, viajam de avião etc. Isso repercute na incorporação de novos gostos, no acréscimo de autoimportância individual e no despertar de ambições pessoais em ocupar posição protagonista ancorado em tal cenário de representação externa. A realização de muitas atividades cotidianas da comunidade passa a ser subordinada à expectativa que seus integrantes depositam no atendimento das demandas apresentadas aos agentes externos, o que nem sempre acontece, provocando a insegurança quanto à previsão do rumo dos acontecimentos. Com isso, o sucesso na obtenção de benefícios para a comunidade, propiciados através da interlocução com as agências externas, é algo que agrega grande prestígio à figura da liderança.

Assim, ao mesmo tempo em que as agências passam a participar do jogo político interno na perseguição do apoio indígena, os índios passam a se utilizar das 
VICTOR FERRI MAURO - Etnogênese e reelaboração da cultura entre os krahô-kanela...

agências na luta por seus objetivos que são, simultaneamente, representativos de interesses de grupos na luta política interna e do conjunto do povo ante a sociedade nacional (ARRUDA, 2001, p. 57).

\section{Reelaboração da cultura}

Como existe uma grande dependência da proteção e da assistência que $\mathrm{o}$ Estado $\mathrm{e}$ as entidades indigenistas oferecem, $\mathrm{o}$ enaltecimento do protótipo do índio "hiper-real" é mais um ingrediente que estimula os povos indígenas a construírem estrategicamente uma autoimagem modelada ao estereótipo do "bom selvagem". Os grupos emergentes se lançam nessa empreitada com maior intensidade ainda, para compensar a menor presença dos traços fenotípicos e culturais identificáveis como "tipicamente indígenas" pelo senso comum.

$\mathrm{Na}$ região Nordeste, grupos que passavam a se afirmar como indígenas a partir das primeiras décadas do século XX tiveram que reforçar os contrastes de sua alteridade em relação à sociedade do entorno adotando elementos culturais - principalmente a dança do toré - como condição para serem reconhecidos pelo órgão de assistência oficial: primeiro o SPI, depois a FUNAI. Conforme o relato de Peres,

Inspetores do SPI atribuíam ancestralidade indígena a partir da verificação de sinais tangíveis como conservação da dança primitiva do tore e a vida em regime tribal. O toré, uma dança reconhecida como compondo o "patrimônio folclórico" das comunidades rurais, foi estabelecido então como o braço emblemático da indianidade e da religiosidade indígena do Nordeste. Movimentos de identidade étnica foram conduzidos na esfera da experiência religiosa e ao mesmo tempo o toré foi politizado e transformado em instrumento de legitimidade na luta pela terra e em espaço de produção discursiva sobre as relações interétnicas. Religiosidade e etnicidade estão estreitamente ligadas nos "levantamentos de aldeia", ou seja, novos grupos étnicos emergem como ramificações daqueles já constituídos que ensinam como entrar em contato com os encantados (PERES, 2011, p. 323).

Diante das circunstâncias mencionadas, torna-se frequente entre

Espaço Ameríndio, Porto Alegre, v. 7, n. 1, p. 37-94, jan./jun. 2013. 
VICTOR FERRI MAURO - Etnogênese e reelaboração da cultura entre os krahô-kanela...

os grupos indígenas a preocupação com a adoção de uma política do que eles chamam de "resgate cultural", que aspira uma volta ao passado para recuperar uma suposta "essência cultural" perdida no decorrer de várias gerações pelo processo de aculturação, que no presente pode ser instrumentalizada em favor de possíveis ganhos coletivos e da projeção futura de um modelo de sociedade idealizado por eles.

Bartolomé descreve que

Nos processos de afirmação étnica, e em especial nos encontros interétnicos, é comum recorrer-se a emblemas identitários, isto é, a traços materiais ou ideológicos, próprios ou apropriados, que indiquem explicitamente a identidade de seus possuidores; assim, as roupas ou 0 artesanato $[\ldots]$ são ressignificados e passam a deter um valor emblemático, ausente em seu uso cotidiano (ou na falta do uso) (BARTOLOMÉ, 2006, p. 55).

Se esses traços culturais são acionados e realçados através de performances e discursos em situações extracotidianas na interação com a sociedade externa, e principalmente perante funcionários e membros de instituições estatais ou grupos de apoio, é justamente porque nessas ocasiões consideram importante demarcar as fronteiras da identidade que separam o nós do Outro, em termos que julgam serem mais compreensíveis para seus interlocutores e que esperam ser capazes de surtir o efeito desejado (BARTOLOMÉ, 2006). Como afirma Cardoso de Oliveira (1976),

um membro de um grupo indígena não invoca sua pertinência tribal a não ser quando posto em confronto com membros de uma outra etnia. Em isolamento, o grupo tribal não tem necessidade de qualquer designação específica (CARDOSO DE OLIVEIRA, 1976, p. 36).

De fato, no dia a dia, quando os índios de maior interação com a sociedade nacional estão em lugares onde vivem e por onde circulam rotineiramente, quase sempre utilizam exclusivamente as vestimentas do padrão ocidental que incorporaram no contato interétnico: calça, camisa, camiseta, chapéu, boné, vestido etc.

Em estudo sobre a comunidade Pankararu em São Paulo, 
VICTOR FERRI MAURO - Etnogênese e reelaboração da cultura entre os krahô-kanela...

Albuquerque (2007) mostra que performances de tradições indígenas são feitas em arenas específicas (museus, universidades, feiras, eventos etc.), inclusive como forma de obtenção de receita econômica. Nesses espaços, a arte étnica pode ser exibida e consumida. As ações governamentais que apóiam tais iniciativas também ganham visibilidade. $\mathrm{O}$ autor considera que esse tipo de apresentação segue um modelo de representação oficial e midiática das tradições indígenas, construção arbitrária homogeneizadora, que nega o caráter atual, múltiplo e contra-hegemônico dessas tradições.

Fazendo alusão ao trabalho de James Clifford (1998), Albuquerque (p.86) afirma que esse modelo seria o do "museu", que "impõe à representação das tradições indígenas o duplo papel de anonimato e de neutralidade histórica espacial" (ALBUQUERQUE, 2007, p. 86). Nessa representação do encontro colonial, acredita-se que as tradições cultuais indígenas precisam ser preservadas para sobreviver.

Percebe-se uma convergência desse discurso com aquilo que Pacheco de Oliveira (1999) constatou a respeito da noção de índio presente no imaginário dos sertanistas:

No entendimento dos sertanistas, os índios são apenas um repositório de virtudes prestes a serem perdidas mediante o contato interétnico. Atualizam assim a imagem do "bom selvagem" e dedicam portanto todos os seus esforços justamente àquelas situações em que os índios ainda não estão corrompidos pelas instituições dos brancos. O que consideram ideal - mas sabem ser impossível - seria estabelecer uma redoma protetora em torno das sociedades indígenas, algo que não permitisse levar-Ihes influências exógenas, com as nefastas necessidades e dependências que estas lhes acarretam (PACHECO DE OLIVEIRA, 1999, p. 201).

Segundo Albuquerque (2007), não é apenas o Estado que aciona esses tipos de discursos e representações sobre o indígena na atualidade. A arte, a ciência e os textos jurídicos, os informativos das ONGs, por exemplo, também corroboram, de certa forma, essa ideia de "preservação" da cultura.

[...] lançar mão de um modelo estereotipado de um componente social marginalizado (o índio) virou consenso entre as ideologias de esquerda e de direita 
VICTOR FERRI MAURO - Etnogênese e reelaboração da cultura entre os krahô-kanela...

que reivindicam, cada uma a seu modo, o monopólio da representação da assimilação dos diferentes componentes sociais na formação do Estado-nação Brasil (ALBUQUERQUE, 2007, p. 79).

Nesse processo de reconstrução da autoimagem, os indígenas não são meramente atores passivos. Eles buscam intencionalmente, e com fins estratégicos, sincronizar suas autorrepresentações com as representações oficiais de si. Baseado nos ensinamentos de Taussig (1993), Albuquerque (2007) explica como a representação indígena que é exibida na prática performática é construída de forma dialógica e intersubjetiva na interação com outros agentes:

[...] no encontro colonial, a alteridade é também um outro lado da mimese e seu inverso, pois a diferença é "capturada", reproduzida num modelo, que é ao mesmo tempo o outro, mas sob a forma (modelo novamente) do mesmo, mimese. Deste modo, toda a discursividade (e administração) deste encontro passou pela estratégia de "recortar" o outro, de "modelá-lo" a fim de torná-lo semelhante, e com isso criar poder sobre este outro, poder criado no momento em que o outro é "capturado", administrado. As ênfases dessa discursividade revelam os modelos em disputa pela hegemonia sobre a representação do encontro colonial, e é aí que os discursos sobre a diferença e a mimese se interpenetram e criam estratégias de inclusão uns nos outros (ALBUQUERQUE, 2007, p. 89).

Temos visto que os índios utilizam habilmente a seu favor as representações românticas sobre eles criadas pelos não índios para despertar a má consciência destes pelas injustiças históricas cometidas pela sociedade brasileira ao longo de mais de quinhentos anos de colonização. Com sagacidade, os índios ainda encampam o discurso do salvacionismo ecológico propalado pelos ambientalistas nas últimas décadas para angariar apoios estratégicos para a sua causa, já que no imaginário popular o indígena é pensado como um ser que vive em harmonia com a natureza (PACHECO DE OLIVEIRA, 2002, p. 263).

A antropóloga Manuela Carneiro da Cunha (2011) observa com muita propriedade que:

A cultura original de um grupo étnico, na diáspora ou em situações de intenso contato, não se perde ou se 
VICTOR FERRI MAURO - Etnogênese e reelaboração da cultura entre os krahô-kanela...

funde simplesmente, mas adquire uma nova função, essencial e que se acresce às outras, enquanto se torna cultura de contraste: esse novo princípio que a subtende, a do contraste, determina vários processos. A cultura tende ao mesmo tempo a se acentuar, tornando-se mais visível, e a se simplificar e enrijecer, reduzindo-se a um número menor de traços que se tornam diacríticos (CARNEIRO DA CUNHA, 2011, p. 237).

No processo de fortalecimento de suas identidades, os próprios indígenas, sobretudo os grupos em emergência étnica, reivindicam para si a pecha de "índio puro" (cultural e, até mesmo, biologicamente), rechaçada há algum tempo pelo universo acadêmico. Esse processo de uma suposta "purificação" do ser indígena pode ser perpassado por algumas condições, como a reificação das tradições, o estabelecimento de um regime de indianidade enquanto suporte da identidade, a regulação matrimonial através da prescrição e da proscrição de casamentos e a demanda pela demarcação de territórios exclusivos. A prática da "purificação" revela, portanto, um paradoxo: "se aparentemente ela desessencializa as identidades indígenas, formulando a identidade como um jogo de espelhos, sua eficiência exige o jogo implícito de critérios eminentemente essencialistas" (VIVEIROS DE CASTRO et al, 2003, p. 62).

A intensificação das relações com a sociedade envolvente tem acelerado o processo de mudanças culturais nas comunidades indígenas, porém, sem necessariamente ocasionar a assimilação ou a perda da identidade. De acordo com Caleffi, "as identidades indígenas têm se mantido porque justamente suas culturas estão vivas e são capazes de ressignificarem novas realidades, novos objetos e se adaptarem a novas condições de vida" (CALEFFI, 2003, p. 195).

Carneiro da Cunha (2011) também destaca que a cultura não é um dado imanente e fixo, mas algo constantemente reformulado e revestido de novos significados. Elementos culturais são extraídos de seu contexto original e submetidos a rearranjos e simplificações para se tornarem diacríticos; consequentemente, sobrecarregados de sentido, vindo a servir como símbolos da resistência étnica.

$\mathrm{Na}$ verdade, por trás do discurso do resgate cultural, os indígenas estariam ressignificando a sua cultura a partir da ostentação de sinais 
VICTOR FERRI MAURO - Etnogênese e reelaboração da cultura entre os krahô-kanela...

revestidos de uma forte carga simbólica; com a pretensão, consciente ou não, de contemplar a representação que o senso comum ocidental tem do que é ser índio, para marcarem uma alteridade radical em relação à população do entorno, demarcando a fronteira étnica por contraste.

Muitos dos traços culturais emblemáticos (danças, cantos, adereços, pinturas corporais etc.) dos quais se revestem os índios emergentes, quando não inventados, são tomados de empréstimo de sociedades indígenas consideradas mais apegadas à "tradição" ameríndia, o que supõem conferir uma áurea de "autenticidade" para os agentes do campo indigenista. Deste modo, podemos perceber que "[...] os discursos e as práticas tradicionais adquirem outros sentidos, que ultrapassam a dinâmica social 'interior', projetando-se como ideologia política no terreno das relações com a sociedade envolvente" (ARRUDA, 2001, p. 58).

Em um processo de etnogênese, para se tornar mais convincente em suas pretensões de reconhecimento oficial, é comum o grupo que pretende realçar a sua identidade lançar mão de um artifício que Hobsbawm e Ranger (1997) chamam de "tradição inventada", que é precisamente

Um conjunto de práticas, normalmente reguladas por regras tácitas ou abertamente aceitas. Tais práticas de natureza ritual ou simbólica visam inculcar certos valores e normas de comportamento através da repetição, o que implica, automaticamente, uma continuidade em relação ao passado, aliás, sempre que possível, tenta-se estabelecer uma continuidade com um passado histórico apropriado (HOBSBAWM e RANGER, 1997, p. 9).

Os sentidos que orientam a identidade estão contidos nas histórias contadas sobre si mesmos e nas memórias e imagens construídas que conectam o presente com o passado, que representam experiências compartilhadas de triunfos e reveses. Histórias que se passaram na trajetória de um determinado povo são contadas e recontadas pelos mais velhos aos mais jovens, às vezes, como se fossem acontecimentos épicos. Personagens que existiram de verdade podem se transformar em uma espécie de mitos fundadores, heróis de 
VICTOR FERRI MAURO - Etnogênese e reelaboração da cultura entre os krahô-kanela...

uma história que localiza a origem do grupo étnico num passado distante. Nesse caso, não em um tempo cronológico, mas em um tempo mítico (HALL, 2006; ANDERSON, 1989). As narrativas atuais representam tais mitos fundadores como a personificação da "essência" da etnicidade, que assegura a extensão dela aos seus descendentes.

É muito importante percebermos que

Ao tematizar e dar caráter reflexivo à sua cultura e à sua ligação com o passado, o grupo está retirando do fluxo contínuo aquilo que deseja preservar, transformar em símbolo e, por isso, fixar, rompendo justamente com seu caráter de hábito que submete aqueles elementos a uma permanente mutação, para alçá-los a um novo estatuto, o de uma tradição, nesse sentido, sempre inventada (ARRUTI, 1997, p. 29).

Também não podemos deixar de considerar que

Esta reconstrução histórica e identitária tende a admitir distintos níveis de incongruências e de lacunas com relação a uma possível "verdade" historiográfica, já que não Ihe importa tanto a coerência formal do relato ou da narrativa étnica construída, mas sua capacidade de se referir à vida social e de lhe dar um novo sentido (BARTOLOMÉ, 2006, p. 58).

Bartolomé (2006) argumenta que, no caso de comunidades em processo de etnogênese, as identificações não são "inventadas" aleatoriamente (no sentido de dissimulação), mas se atualizam, recuperando um passado próprio, ou assumido como próprio, tendo em vista a reconstrução de um pertencimento comunitário que possibilite o acesso a condições de vida mais dignas no presente. Nas palavras do próprio autor:

Construir uma ideologia coletiva em termos étnicos [...] implica uma busca no passado para instituir uma nova relação com a realidade contemporânea. É uma tentativa de superar a deshistorização de que padecem os povos colonizados e reconstruir uma história, talvez fragmentária, mas tida como fundamental para recompor uma noção de coletividade, de comunidade histórica que deve se reencontrar com suas origens confusas ou mitificadas a fim de reivindicar, em face dos outros e de si mesma, sua legitimidade passada e

Espaço Ameríndio, Porto Alegre, v. 7, n. 1, p. 37-94, jan./jun. 2013. 
VICTOR FERRI MAURO - Etnogênese e reelaboração da cultura entre os krahô-kanela...

presente (BARTOLOMÉ, 2006, p. 57-58).

E é por essa razão que Viveiros de Castro et al (2003) opinam que

a questão de saber se as etnias emergentes do Nordeste estão virando índios de novo ou 'pela primeira vez' - porque algumas destas comunidades não teriam 'continuidade histórica demonstrável' com algum povo pré-colombiano - não faz, a nosso ver, qualquer sentido (VIVEIROS DE CASTRO et al, 2003, p. 63 grifos dos autores),

levando em conta que "o devir-índio envolve ema relação dos povos indígenas com seu passado, mas se trata de uma relação presente com o passado, não de uma relação passada com o presente" (VIVEIROS DE CASTRO et al, 2003, p. 63 - grifos dos autores).

Arruti (1997) ressalta que nesses processos de afirmação identitária, os antigos elementos da cultura e da história são mobilizados como repertório de símbolos, rituais e personagens exemplares que atendem a novos fins. Não há um compromisso estreito com a veracidade de como o fato ocorreu no passado. Os elos de ligação das comunidades do presente com os grupos do passado necessitam ser produzidos no momento atual, por meio da seleção e recriação de elementos da memória, através de traços culturais que possam ser utilizados como sinais diacríticos identificáveis pelos mediadores e pela agência que detém a autoridade de reconhecer oficialmente a identidade indígena - no caso, a FUNAI. Os elementos culturais que distinguiam os indígenas da sociedade envolvente, e que anteriormente eram os sinais de seus estigmas, passam a ser assumidos com uma conotação positiva para si. Os limites da fronteira étnica, antes mais porosos, se enrijecem e adquirem novos critérios de diferenciação. Genealogias e parentescos horizontais são resgatados como provas de pertencimento ou não de indivíduos no grupo.

Sampaio (2006), se referindo ao caso concreto entre os Pataxó, do litoral sul da Bahia, ponderou:

[...] a idéia de resgate cultural pode ser percebida como uma espécie de proposição de anulação da história; um procedimento pelo qual se poderia, ao menos em parte, devolver às sociedades indígenas a 
VICTOR FERRI MAURO - Etnogênese e reelaboração da cultura entre os krahô-kanela...

sua essência perdida e, no limite, fazê-las retornar ou reviver o seu estado original de encantamento e de verdadeira diversidade (SAMPAIO, 2006, p. 170).

Em inúmeros casos, as escolas indígenas têm sido usadas como um dos principais veículos transmissores da ideologia do "resgate cultural", reproduzindo constantemente em sala de aula estereótipos folclorizados dos índios tal como se faz na maioria das escolas brasileiras no dia 19 de abril, o "Dia do Índio". Nas séries iniciais, estimula-se a produção de recortes e colagens de figuras e desenhos que retratam índios paramentados, com cocar na cabeça, corpo pintado, na floresta, empunhando arco e flecha etc., que depois são afixados nas paredes da classe. Busca-se criar uma identificação das crianças indígenas com essas representações, que, embora românticas, e talvez até positivas em certo ponto de vista, não deixam de estarem calcadas em uma lógica etnocêntrica ocidental que distorce e banaliza a realidade.

O fato de a legislação brasileira assegurar a oferta aos povos indígenas de um modelo de educação específica e diferenciada é, muitas vezes, interpretado como uma necessidade de promover através do ensino o que eles entendem por "resgate cultural". A respeito disso, Sampaio (2006) nos alerta que,

[...] ao se Ihes autorizar [...] uma educação específica e diferenciada, não se deixa de lhes impor, muitas vezes, até mesmo sem que se perceba, a sua redução a um ideal cultural indígena produzido e imposto pela sociedade nacional, e que o imaginário desta tende a identificar ou a aproximar a algumas sociedades indígenas reais, como algumas das da Amazônia...

Opera aqui, então, um processo de dominação cultural no qual os índios são levados a se tornar, a um só tempo, vítimas e cúmplices de um seqüestro no qual o resgate é de fato percebido como um necessário preço a pagar pela obtenção de reconhecimentos à legitimidade de seus pleitos, sobretudo pleitos por direitos diferenciados (SAMPAIO, 2006, p. 172).

Arruda (2001) concorda que, à primeira vista, a retomada da tradição buscada pelas sociedades indígenas se apresenta com aspecto de movimento conservador e restaurador da ordem interna do sistema 
VICTOR FERRI MAURO - Etnogênese e reelaboração da cultura entre os krahô-kanela...

social. Entretanto,

[...] na medida em que a dinâmica social só se reproduz no âmbito das relações do campo da intermediação, a volta à tradição [e, por que não, a sua invenção?] manifesta-se também como resistência política à dominação da sociedade envolvente. A valorização da especificidade cultural é a afirmação da sociedade indígena como sujeito histórico, e constitui a evidência legitimadora de seus direitos como povo (ARRUDA, 2001, p. 58).

A manipulação consciente dos sinais diacríticos que algumas sociedades indígenas promovem enseja uma semiurgia em que 0 significante - neste caso, a imagem mental do "índio genérico" - adquire mais "realidade" que o significado a que se referencia - o de ser indígena -, produzindo uma desreferencialização da realidade, ou uma "hiper-realidade", que está relacionado à noção de "simulacro" empregada por Novaes (1993). Para esta autora, o simulacro seria justamente a imitação que os indígenas fazem da representação instituída pelo grupo dominador - neste caso os "brancos" - a respeito deles. Ela enfatiza que os sinais diacríticos "permitem a manipulação dos estereótipos presentes no imaginário da nossa sociedade a respeito de quem são, afinal, 'os índios'” (NOVAES, 1993, p. 71).

Por mais paradoxal que pareça, esse tipo de simulacro é visto pela autora como uma estratégia calculada, que deriva da "necessidade de constituição de sujeitos políticos que se articulam para reivindicar para si um espaço de visibilidade e atuação social", e se configura como "a possibilidade destes sujeitos políticos atuarem no sentido de romperem a sujeição a que historicamente foram submetidos" (NOVAES, 1993, p. 73-74).

Bartolomé (2006) anuncia que em muitos casos os nativos se apropriam de conteúdos de textos produzidos por antropólogos, historiadores e outros pesquisadores, dedicados à história e à cultura do grupo, conferindo a eles uma dimensão política e social que originalmente não havia sido projetada pelos autores. Nesse processo, tais obras tornam-se referência para a solidificação da ideologia étnica. Bartolomé (2006) adverte, porém, que tal manipulação da história não consiste em uma falsificação ou em uma construção ilegítima, mas no 
VICTOR FERRI MAURO - Etnogênese e reelaboração da cultura entre os krahô-kanela...

emprego de todas as estratégias acessíveis que possam servir para o grupo se recompor enquanto coletividade distintiva.

A manipulação dos traços diacríticos da cultura, neste caso, não pode ser pensada como ação com finalidade espúria, mas como estratégia de sobrevivência que praticamente todas as sociedades adotam. Schwarcz (2007) observa que

Culturas se criam, alteram-se e se resignificam e não há outra saída, como bem mostrou o antropólogo Roy Wagner, senão "inventar". Acusar a invenção de algo é, assim, um exercício tão ingênuo quanto fadado ao fracasso: os homens sempre manipularam e foram manipulados por suas culturas (SCHWARCZ, 2007, p. 20).

De forma muito pertinente, a mesma autora destaca que na atualidade as evidências demonstram que, na maior parte dos casos, um grupo étnico é causa de sua cultura e não consequência da mesma, considerando que

Grupos étnicos criam culturas, traduções, expectativas, memórias e até naturezas. A própria noção de identidade [...] essa voga tão atual - não pode, pois, ser entendida como ponto de chegada (uma tomada de consciência das origens); ela é chave de partida. Aqui se abre, e não se fecha, uma longa negociação relativa aos dilemas da própria instituição da memória (SCHWARCZ, 2007, p. 20).

Sahlins (1997) constata que a estrutura planetária da cultura está se transformando. Nos tempos atuais se vivencia "uma nova organização mundial da cultura e dos novos modos de produção histórica" (SAHLINS, 1997, p. 133). A cultura global se dissemina em escala planetária pelos canais de integração econômica; porém, concomitantemente, ao se inflectirem em âmbito local, esses fluxos globais adquirem formas variadas em conformidade com esquemas culturais específicos.

Dada essa ordem estrutural, não há sentido em lamentar por "inautênticas" as formas de adaptação dos povos locais ao Sistema Mundial, sequer quando eles se apropriam das imagens ocidentais do "nativo" como signos de sua própria alteridade - seja com propósitos aparentemente benignos (como quando os "nativos" 
VICTOR FERRI MAURO - Etnogênese e reelaboração da cultura entre os krahô-kanela...

utilizam, em benefício próprio, toda a sabedoria ecológica que o movimento ambientalista global Ihes imputa), sejam com propósitos explicitamente comerciais (como na exploração do mercado turístico ávido de danças "nativas", artefatos ou coisa que valha). É assim que se faz hoje a história cultural, em um intercâmbio dialético do global com o local. Pois ficou bem claro agora que o imperialismo não está lidando com amadores nesse negócio de construção de alteridades ou de produção de identidades (SAHLINS, 1997, p. 133).

O afã de ostentar sinais diacríticos também parece ter como objetivo a minimização da discriminação que alguns integrantes de outras etnias indígenas brasileiras, conhecidas há mais tempo, têm em relação aos índios emergentes, tratando estes como se fossem menos "autênticos". Integrantes dos grupos emergentes com frequência sofrem esse tipo discriminação perpetrada também por indígenas de etnias legitimadas pelo Estado há muito tempo. Carregam o duplo estigma de serem índios e de "não parecerem" índios.

Bartolomé (2006) pondera que a ostentação acintosa da identidade costuma confundir os observadores externos, que podem encará-la como mero exibicionismo étnico interessado. Contudo, conforme explica o autor, o ato não necessariamente está relacionado a intenções e interesses espúrios. Segundo ele,

Podem-se mobilizar recursos lingüísticos ou culturais para alcançar determinados propósitos, porque tais recursos de alguma maneira existem e não necessariamente estão sendo inventados naquele momento. A manipulação da identidade étnica não inclui obrigatoriamente a mentira ou a falsificação, embora indubitavelmente possa ser um recurso para a ação (BARTOLOMÉ, 2006, p. 55).

Arruti (1997) admite que o caráter pragmático das emergências étnicas indígenas é indiscutível, mas acrescenta que há outros aspectos envolvidos nesse processo: as lutas comuns e os rituais compartilhados que são retomados ou "inventados" ajudam a conferir uma elevada relevância normativa, afetiva e valorativa às identidades assumidas, propiciando condições para a ascensão ao redor daqueles sujeitos históricos de uma "comunidade imaginada" - nos termos de Anderson 
VICTOR FERRI MAURO - Etnogênese e reelaboração da cultura entre os krahô-kanela...

(1989) -, em que está presente e bastante fortalecido entre os seus integrantes o sentimento de unidade, origem e destino comuns.

Luciano (2006) nos conta que a recuperação do valor do significado da identidade indígena é uma preocupação mais perceptível entre as gerações mais novas do que entre os mais velhos. A tradição tem sido vista por eles como um espaço social e identitário que serve de passaporte de entrada na modernidade com mais autonomia e dignidade, pois fundamenta a garantia do acesso aos direitos econômicos, sociais, culturais contemporâneos. As gerações mais antigas, por sua vez, demonstram maior resistência à reafirmação das identidades étnicas, em razão dos traumas e preconceitos vividos no passado por causa do estigma da filiação tribal. Ainda assim, muitos velhos e anciãos estão superando essa barreira psicológica e embarcando no movimento trilhado pelos mais jovens.

Tratando dos povos indígenas de uma maneira geral, Arruda (2001) observa que, se, por um lado, a ampliação do mundo tribal devido à interação mais constante com a população não indígena e com seus costumes diminui o poder dos mais velhos, que são os portadores da tradição; por outro, as ameaças atreladas à expansão da sociedade global sobre os povos indígenas requerem a revalorização da tradição como recurso para a legitimação de seus direitos históricos na condição de povos diferenciados em termos de cultura. Deste modo, se inicialmente a hierarquia costumeira é subvertida, numa fase posterior, a ordem social é reorientada, quando o desempenho das novas atividades é subordinado ao crivo da tradição. O conhecimento da tradição torna-se requisito até mesmo para ocupar postos de comando e responsabilidade, e, portanto, passa a ser fonte de prestígio social. Os jovens redobram o interesse pelo aprendizado das práticas tradicionais: o canto, a dança, as rezas, os ritos. Assim, o controle das escolhas retorna para as mãos dos mais velhos.

Entre os povos indígenas emergentes, para que os símbolos compartilhados sejam assumidos como emblemas pela coletividade, devem encontrar ressonância entre alguns guardiões da memória coletiva local (geralmente os anciãos e alguns intelectuais orgânicos), que conferem legitimidade diante do círculo cultural mais próximo. 0 descontentamento destes com a atualidade fazem-nos enaltecer $o$ 
VICTOR FERRI MAURO - Etnogênese e reelaboração da cultura entre os krahô-kanela...

passado, que buscam revisitar ou recriar para "refrescar" a memória coletiva. Arruti (1997) observa que no processo de constituição de grupos indígenas emergentes, a reelaboração da memória coletiva, com a elevação do status dos portadores dessa memória, pode influenciar na nomeação de chefias e na criação de formas de ordenamento político.

Para Luciano, não há contradição nenhuma nesse pêndulo entre tradição ancestral e modernidade. Ele argumenta que

\begin{abstract}
Entrar e fazer parte da modernidade não significa abdicar de sua origem nem de suas tradições e modos de vida próprios, mas de uma interação consciente com outras culturas que leve à valorização de si mesmo. Para os jovens indígenas, não é possível viver a modernidade sem uma referência identitária, já que permaneceria o vazio interior diante da vida frenética aparentemente homogeneizadora e globalizadora, mas na qual subjazem profundas contradições, como a das identidades individuais e coletivas (LUCIANO, 2006, p. 40).
\end{abstract}

\title{
O caso dos Krahô-Kanela
}

Toda a discussão teórica feita até aqui se aplica bem para analisar o exemplo da comunidade indígena Krahô-Kanela. Esse grupo alega descender de indivíduos que integravam os povos Krahô e Kanela (ambos de tradição Timbira) e que se distanciaram da convivência tribal, por circunstâncias compulsórias, ainda no final do século XIX. Tendo perambulado por várias localidades do antigo norte de Goiás (atual Tocantins) ao longo de muitas décadas, as gerações subsequentes foram se casando com não indígenas e transformando os costumes com o passar do tempo, ao ponto que começaram a ser chamados de "caboclos" pelos habitantes da região, sem se incomodarem muito com isso (MAURO, 2011 ).

$\mathrm{Na}$ década de 1980 passaram a ostentar a identidade indígena, ocultada até então, e utilizá-la para reivindicar junto à FUNAl ações no sentido de regularizar a posse de um território de onde haviam sido expulsos em 1976 e que ocupavam desde o início da década anterior.

Dirigentes e técnicos do órgão indigenista, por sua vez, 
VICTOR FERRI MAURO - Etnogênese e reelaboração da cultura entre os krahô-kanela...

recusavam-se a atender às demandas do grupo, por considerarem que não se tratava de índios de fato.

Em 1988, uma advogada da FUNAl chegou a apresentar um parecer ao chefe da superintendência regional do órgão em Goiânia afirmando que o grupo em questão não se enquadrava na definição de "índio" descrita pela Lei 6.001/73 (Estatuto do Índio), e que, assim sendo, a FUNAl não poderia assumir a responsabilidade de assistir aquela comunidade quanto à sua demanda por demarcação de terras.

Se referindo ao grupo como os "caboclos", a advogada afirmava que esses indivíduos

[...] estão identificados à maioria da população do Médio Norte Goiano e a Matogrossense - remotos descendentes de índios. O produto da miscigenação do pré-colombiano, lusitano e africano, deu origem a raça autenticamente brasileira, que se faz mais presente na região central do país. Dessa miscigenação no CentroOeste Brasileiro, predominou um tipo étnico característico, o cafuso, resultante acaboclado do silvícola e preto, dominante é o gene índio, por isso a semelhança fisionômica deles com a raça précolombiana (BRASIL, 1988, p. 10).

Dois anos mais tarde, um documento encaminhado pelo superintendente da FUNAI em Goiânia ao superintendente do IBAMA em Tocantins reiterava a discriminação contra esse grupo que estava vivendo na Ilha do Bananal desde 1987, com autorização da própria agência indigenista oficial. No documento mencionado, o superintendente da FUNAI assim se expressava:

[...] informo-vos que, escapa à Fundação Nacional do Indio tutelar esses caboclos, que na verdade, não passam de cidadãos comuns portadores de remota ascendência indígena, como a maioria da população da Região Central do País. Ressalto que, a minha assertiva acima, tem razão de ser embasado no longo estudo elaborado por técnicos da FUNAI, visando encontrar a origem do grupo, restando, não obstante, infrutífera esta identificação. [...] Informo, todavia, que já demos prosseguimento à ação de retirada de todos os intrusos e impostores que indevidamente ocupam e tiram proveito das terras indígenas, nesse proceder, contamos com a valiosa colaboração do Instituto Brasileiro de Meio Ambiente (BRASIL, 1990, s./p.). 
VICTOR FERRI MAURO - Etnogênese e reelaboração da cultura entre os krahô-kanela...

Mesmo antropólogos a serviço da FUNAI não se sentiam seguros em atestar a legitimidade da identidade autoatribuída, pois não encontraram naquele grupo a presença de elementos culturais e fisionômicos que consideravam necessários como indicadores de uma continuidade histórica com povos de origem pré-colombiana.

Os Krahô-Kanela chegaram a ser retirados da Ilha do Bananal pela FUNAI e levados para um assentamento da reforma agrária do INCRA em 1999. De lá foram removidos para outros lugares, onde também não se adaptaram. Somente depois de muita luta e resistência, em 2002 os Krahô-Kanela tiveram a identidade indígena reconhecida oficialmente; em boa medida, por força da ratificação da Convenção $n^{\circ} 169$ da Organização Internacional do Trabalho (OIT) pelo Congresso Nacional, naquele ano.

Em 2006, parte do território que reivindicavam foi desapropriada para o assentamento das famílias indígenas que viveram 30 anos fora dali. A trajetória de mobilizações políticas e de articulações para angariar apoio do movimento indígena, da sociedade civil organizada, do Ministério Público Federal e de políticos foi muito intensa e cheia de reveses e sofrimento. Mesmo depois do reconhecimento oficial, houve um presidente da FUNAI que desqualificou a identidade dos KrahôKanela (MAURO e EREMITES DE OLIVEIRA, 2010).

$\mathrm{Na}$ trajetória recente desses indígenas, a construção da autoimagem convergente com as representações estereotipadas do "índio genérico" foi e continua sendo efetuada e instrumentalizada no objetivo de consolidar o reconhecimento de sua indianidade pela sociedade envolvente, pelo Estado e por outros povos indígenas há mais tempo legitimados.

No contato que as lideranças krahô-kanela fazem com indígenas de outros povos que participam do movimento social, tomam conhecimento de manifestações culturais materiais e imateriais desses grupos, tomando de empréstimo e incorporando parte desses elementos, que são interpretados e ressemantizados para adaptarem ao novo contexto em que são postos em prática.

A comunidade krahô-kanela da aldeia Lankraré elaborou um projeto intitulado "Resgate da Cultura Krahô-Kanela", que foi uma das 
VICTOR FERRI MAURO - Etnogênese e reelaboração da cultura entre os krahô-kanela...

ações aprovadas no Prêmio Culturas Indígenas 2007 - Edição Xicão Xukuru, do Ministério da Cultura. Duas frases do projeto, citadas no catálogo da premiação, deixam transparecer o entusiasmo desse grupo indígena em se aproximar dos Krahô para aprender e cultivar vários de seus traços culturais, em um movimento de um suposto retorno ao passado, uma viagem de volta pelos caminhos que os seus antepassados trilharam.

$\mathrm{Na}$ justificativa do projeto está posto: "O maior anseio da nossa comunidade é resgatar tudo que perdemos da nossa cultura tradicional" (BRASIL, 2007, p. 115). A promoção desse "resgate" se daria através de determinadas iniciativas pretendidas, como revela o parágrafo abaixo citado.

Pretendemos trazer três famílias de uma aldeia Krahô para que nos ensinem a falar a lingua materna, fazer artesanatos, corridas de tora, corridas de varinhas e outros costumes. Uma vez, vieram 18 Krahô em nossa aldeia, dançaram, cantaram, tocaram maracá, tocaram as cabacinhas, e nós acompanhamos passo a passo, aprendemos muita coisa. Isso nos deixou muito felizes. Queremos fazer outro encontro com mais tempo, assim todos os membros da comunidade participarão da iniciativa. Além de reaprender danças, cantos e jogos da nossa cultura, queremos também contratar um professor Krahô para dar aula na língua materna em nossa escola (BRASIL, 2007, p. 115).

Nos últimos anos, o CIMI e a FUNAl têm empreendido ações visando estreitar os laços de amizade entre alguns grupos Krahô e a comunidade krahô-kanela da aldeia Lankraré através da promoção de intercâmbios de curta duração. Outras iniciativas desenvolvidas são as que estimulam a confecção de artesanato e a realização de danças, jogos e ritos que os jovens krahô-kanela têm tentado aprender com os Krahô. Os Krahô-Kanela pleiteavam para a sua escola a contratação de um professor krahô que lhes ensinasse as tradições, os mitos e a língua desse povo. Dificilmente a nova língua a ser aprendida pelas crianças se tornaria funcional no cotidiano krahô-kanela, já que a comunidade se comunica apenas em português. Porém, os vocábulos Krahô serviriam para reforçar a alteridade através do contraste com a cultura dos não índios.

Espaço Ameríndio, Porto Alegre, v. 7, n. 1, p. 37-94, jan./jun. 2013. 
VICTOR FERRI MAURO - Etnogênese e reelaboração da cultura entre os krahô-kanela...

Ao receberem uma equipe do programa de TV Globo Repórter em sua aldeia, em 2010, os Krahô-Kanela apresentaram uma dança que aprenderam com os Krahô. Para enfatizar um caráter de exotismo cultural, o cacique Mariano chegou a dizer diante das câmeras que os Krahô-Kanela comem onça, o que depois confidenciou a mim não ser um fato verdadeiro.

Tive a impressão de que alguns jovens dessa comunidade mais engajados no movimento social indígena sentem um certo incômodo por causa de seus traços fenotípicos "miscigenados", que às vezes tornam-se motivos de gracejos por parte de índios de outras etnias que se consideram mais "puros". Alguns servidores mais antigos da FUNAI, ainda que disfarcem, continuam os vendo como índios menos "autênticos" do que os dos demais povos do Tocantins. De algum tempo para cá, esses jovens têm sido estimulados por membros da sua comunidade a se casarem com indígenas de outras etnias, no intuito de gerar filhos com fenótipo mais semelhante ao que se imagina como "tipicamente" indígena, e apagar os traços da suposta "mistura racial".

\section{Conclusão}

A pretensão de serem acolhidos e reconhecidos pelas demais etnias que atuam no movimento indígena motiva mais ainda os KrahôKanela e outros povos a realçarem a sua autoimagem pelo uso dos sinais diacríticos. Investem na busca do reconhecimento da identidade não só porque ela pode dar acesso ao gozo de direitos especiais, mas também porque a esse tipo de reconhecimento está atrelada a sua dignidade própria enquanto coletividade. No que concerne ao reconhecimento social, a perspectiva do filósofo Charles Taylor (1994) se aplica bem à analise de caso dos índios em questão, se considerarmos que

[...] a luta contra o racismo apresenta-se, então, como um ideal democrático de maior igualdade de condições,

\footnotetext{
${ }^{6}$ TRIBO DOS KRAHÓ KANELA EXIBE SUA DANÇA DA SAÚDE E DA GENEROSIDADE. Portal de notícias Globo.com, 17/09/2010. Disponível em: <http://g1.globo.com/globoreporter/noticia/2010/09/tribo-dos-kraho-kanela-exibe-sua-danca-da-saude-e-da-generosidade.ht $\mathrm{ml}>$. Acesso em: 28/09/2012.
}

Espaço Ameríndio, Porto Alegre, v. 7, n. 1, p. 37-94, jan./jun. 2013. 
VICTOR FERRI MAURO - Etnogênese e reelaboração da cultura entre os krahô-kanela...

e também como um esforço visando ao reconhecimento de status e de dignidade, que passa pela partilha do poder e pelo igual acesso aos bens materiais e às posições de prestígio (D'ADESKY, 2001, p. 23).

Para as comunidades indígenas emergentes, o reconhecimento oficial de sua identidade é de suma importância, pois, além de assegurar o acesso a direitos especiais, isso lhes confere um sentimento de dignidade. Podemos perceber que

O reconhecimento pode ser considerado como a dimensão moral dos direitos, e por isso pertencente a um debate da esfera pública. Embora haja uma dimensão privada, íntima, em que se precisa do reconhecimento para a construção do autorespeito, essa dimensão necessita do aspecto público: o reconhecimento público por meio dos direitos, tanto como demandante capaz de pleitear direitos quanto o reconhecimento da diferença como um direito (MIZUTANI, 2011, p. 14).

Inúmeras são as situações em que se verifica o acionamento da identidade indígena relacionado como uma identificação positiva de si próprio como agente social. Sendo assim, fica patente que os povos emergentes não apenas pleiteiam vantagens materiais, mas também reivindicam o respeito à sua forma diferente de ser, aos seus valores e à sua concepção de mundo. Trata-se, portanto, de uma luta pela cidadania plena.

A recusa do reconhecimento da sua identidade acarreta traumas e infortúnios, pois,

[...] quando o ator não tem sucesso na apresentação da própria identidade, ele está sujeito não apenas ao tratamento com desconsideração, mas, sobretudo, ao desrespeito de seus direitos básicos de cidadania.

[...] O não reconhecimento do valor ou da identidade/substância moral do interlocutor estimula a negação de sua dignidade, podendo inviabilizar o seu tratamento como um igual ou como uma pessoa/ser humano respeitável, igualmente merecedor de atenção, respeito e consideração (CARDOSO DE OLIVEIRA, 2002, p. 107).

Cardoso de Oliveira (2005) constatava que indígenas das faixas

Espaço Ameríndio, Porto Alegre, v. 7, n. 1, p. 37-94, jan./jun. 2013. 
VICTOR FERRI MAURO - Etnogênese e reelaboração da cultura entre os krahô-kanela...

etárias mais jovens vinham assumindo cada vez mais o que denominou como "ideologia de crescente autorrespeito", cujo ponto de partida era a demanda pelo reconhecimento de sua identidade étnica e do direito à cidadania que deve estar atrelado a ela, uma vez que a reivindicação de direitos políticos está alicerçada também em razões de ordem moral e não apenas de caráter político. Através do reconhecimento se vislumbra uma possibilidade de ruptura com a "consciência infeliz", proporcionando assim as condições para o estabelecimento de uma vida ética ou de verdadeira eticidade. $\mathrm{O}$ autor compreendia que a honra e a dignidade dos povos indígenas brasileiros, tão vilipendiada no passado, estava em franca recuperação, pois "a busca pelo respeito de si pelos Outros começa pela descoberta do auto-respeito" (CARDOSO DE OLIVEIRA, 2005, p. 38). As etnogêneses têm participação importante nesse processo, porque representam a retomada do orgulho da identificação como indígena.

\section{Referências bibliográficas}

ADAMS, Cristina; MURRIETA, Rui; NEVES, Walter. Introdução. In: (Org.). Sociedades Caboclas Amazônicas: modernidade e invisibilidade. São Paulo: Annablume, 2006. p. 15-32.

ALBUQUERQUE, Marcos A. S. Mobilização étnica na cidade de São Paulo: o caso dos índios Pankararu. Espaço Ameríndio, Porto Alegre, v. 1, n. 1, p. 73-101, jul./dez, 2007.

ANDERSON, Benedict. Comunidades imaginadas: reflexões sobre a origem e a difusão do nacionalismo. São Paulo: Companhia das Letras, 1989.

ARRUDA, Rinaldo S. V. Imagens do índio: signos da tolerância. In: GRUPIONI, Luís D. B.; VIDAL, Lux; FISCHMANN, Roseli (Org.). Povos indígenas e tolerância: construindo práticas de respeito e solidariedade. São Paulo: Edusp, 2001. p. 43-61.

ARRUTI, José M. A. A emergência dos "remanescentes": notas para o diálogo entre indígenas e quilombolas. Revista Mana,v. 3, n. 2, p. 7-38, 1997.

Etnogêneses indígenas. In: RICARDO, Beto; RICARDO, Fany (Org.). Povos Indígenas no Brasil: 2001-2005. São Paulo: Instituto Socioambiental, 2006. p. 50-54.

ATHIAS, Renato. A Noção da identidade étnica na antropologia brasileira: de 
VICTOR FERRI MAURO - Etnogênese e reelaboração da cultura entre os krahô-kanela...

Roquette Pinto a Roberto Cardoso de Oliveira. Recife: UFPE, 2007.

BARBUJANI, Guido. A invenção das raças. São Paulo: Contexto, 2007.

BARTH, Fredrik. Grupos étnicos e suas fronteiras. In: POUTIGNAT, Philippe; STREIFF-FENART, Jocelyne (Org.). Teorias da etnicidade. São Paulo: Editora da Unesp, 1988. p. 188-227.

BARTOLOMÉ. Miguel A. As etnogêneses: velhos atores e novos papéis no cenário cultural e político. Revista Mana, v. 12, n. 1, p. 39-68, 2006.

BHABHA, Homi. O local da cultura. Belo Horizonte: UFMG, 1998.

BRANDÃO, Carlos Rodrigues. Identidade e etnia: construção da pessoa e resistência cultural. São Paulo: Brasiliense, 1986.

BRASIL. Fundação Nacional do Índio. Ministério do Interior. Parecer $\mathrm{N}^{\mathrm{o}}$ 003/ASS.JUR/GYN/88, Brasília, 1988. p. 10.

BRASIL. Fundação Nacional do Índio. Ministério da Justiça. $6^{\text {a }}$ Superintendência Regional. Goiânia. CI Nº92/GAB/6a SUER, de 27 de junho de 1990.

BRASIL. Senado Federal. Secretaria de Taquigrafia. 16/06/2004. n./p. Disponível em: U:ISacei_Sscom_2004lCom_Esp_Ext_2003_2004lTerrasIndigenas\Notas_Taq L2004061 6.doc. Acesso em: 24 mai 2008.

BRASIL. Advocacia Geral da União. Procuradoria Federal. Procuradoria Federal Especializada. Ofício N 10/PGF-PG/FUNAI/07. Brasília, 2006.

BRASIL. Ministério da Cultura. Prêmio Culturas Indígenas 2007. Edição Xicão Xukuru. Catálogo parte 4, grupo C, Brasília, 2007.

BRASIL. Lei $\mathrm{n}^{\circ} 6.001$ de 19/12/1973 - Dispõe sobre o Estatuto do Índio. In: VILlARES E SILVA, Luiz F. (Org.). Coletânea da Legislação Indigenista Brasileira. Brasília: CGDTI/FUNAI, 2008. p .45-53.

CALEFFI, Paula. “O que é ser índio hoje?”: a questão indígena na América Latina/Brasil no início do século XXI. In: SIDEKUM, Antônio (Org.). Alteridade e multiculturalismo. Ijuí: UNIJUÍ, 2003. p. 175-204.

CARDOSO DE OLIVEIRA, Roberto. Identidade, etnia e estrutura social. São Paulo: Pioneira, 1976.

Identidade étnica, reconhecimento e o mundo moral. Anthropológicas, Recife, v. 16, n. 2, p. 9-40, 2005.

CARDOSO DE OLIVEIRA, Luís R. Direito legal e insulto moral: dilemas da cidadania no Brasil, Quebec e EUA. Rio de Janeiro: Relume Dumará, 2002. 
VICTOR FERRI MAURO - Etnogênese e reelaboração da cultura entre os krahô-kanela...

CARNEIRO DA CUNHA. Manuela. Antropologia do Brasil: mito, história, etnicidade. São Paulo: Brasiliense, 1986.

Cultura com aspas e outros ensaios. São Paulo: Cosacnaify, 2011.

CLIFFORD, James. Sobre a autoridade etnográfica. In: GONÇALVES, José Reginaldo Santos. A experiência etnográfica: Antropologia e Literatura no séc. XX. Rio de Janeiro: Ed. UFRJ, 1998. p. 17-62.

COMISSÃO PRÓ-ÍNDIO. Cadernos da Comissão Pró-Índio/SP. São Paulo: Global Editora, 1979. v. 1.

D’ADESKY, Jacques. Pluralismo étnico e multiculturalismo: racismos e antiracismos no Brasil. Rio de Janeiro: Pallas, 2001.

FERNANDES, Joana. Índio: esse nosso desconhecido. Cuiabá: Editora UFMT, 1993.

FUNAI. Memorando n. 109/PRES/03. Brasília: FUNAI, 2003.

GALLOIS, Dominique T. Sociedades Indígenas em novo perfil: alguns desafios. Travessia, São Paulo, v. 13, n. 36, p. 5-10, 2000a. Disponível em: http://www.institutoiepe.org.br/media/artigos/doc7.pdf . Acesso em: 20 set. 2012.

. Intercâmbio de imagens e reconstruções culturais. Revista Sinopses, São http://www.institutoiepe.org.br/media/artigos/doc6.pdf . Acesso em: 20 set. 2012.

GOMES, Mércio P. "Ser presidente da Funai já é uma glória": entrevista concedida à equipe do Instituto Socioambiental. In: RICARDO, Beto; RICARDO, Fany. (Org.). Povos indígenas no Brasil: 2001-2005. São Paulo: Instituto Socioambiental, 2006. p. 109-116.

HALL, Stuart. A identidade cultural na pós-modernidade. Rio de Janeiro: DP\&A, 2006.

HOBSBAWM, Eric; RANGER, Terence. A Invenção das tradições. São Paulo: Paz e Terra, 1997.

JODELET, Denise. Os processos psicossociais da exclusão. In: SAWAIA, Bader (Org.). As artimanhas da exclusão: análise psicossocial e ética da desigualdade social. Petrópolis: Vozes, 2001. p. 53-66.

LIMA, Deborah M. A construção histórica do termo Caboclo: sobre estruturas e representações sociais no meio rural amazônico. Novos Cadernos NAEA, Belém, v. 2, n. 2, p. 05-32, 1999.

LUCIANO, Gersem S. O índio Brasileiro: o que você precisa saber sobre os povos 
VICTOR FERRI MAURO - Etnogênese e reelaboração da cultura entre os krahô-kanela...

indígenas no Brasil de hoje. Brasília: Ministério da Educação/Secretaria de Educação Continuada, Alfabetização e Diversidade/LACED/Museu Nacional, 2006.

MAURO, Victor F. A trajetória dos índios Krahô-Kanela: etnicidade, territorialização e reconhecimento de direitos territoriais. 2011. 218 f. Dissertação (Mestrado em História) - UFGD, [2011].

MAURO, Victor F.; EREMITES DE OLIVEIRA, Jorge. Os Krahô-Kanela e as políticas de reconhecimento étnico da FUNAI. Revista Opsis, Catalão, v. 10, n. 1, p. 115-143, 2010 .

METRE, Leia. Remanescentes: a luta pela identidade. Revista Brasil Indígena, Brasília, v. 2, n. 10, p. 5-8, 2002.

MINISTÉRIO PÚBLICO FEDERAL. Procuradoria da República do Estado do Amazonas. Portaria Nº 29/2011. 5º Ofício Cível/PR/AM. 25 de março de 2011.

MIZUTANI, Larissa C. Terra com e sem lei: o reconhecimento das minorias e o poder judiciário. In: Anais do XI Congresso Luso Afro Brasileiro de Ciências Sociais. Salvador: UFBA, 2011.

MOONEN, Frans. Antropologia aplicada. São Paulo: Ática, 1988.

MOONEN, Frans. Povos Indígenas no Brasil. In: MOONEN, Frans; MAIA, Luciano M. (Org.). Etnohistória dos Índios Potiguara. João Pessoa: SEC/PB, 1992. p. 13-92.

NASCIMENTO, Adir C. Educação indígena: palco das diferenças. Campo Grande: UCDB, 2004.

NOVAES, Sylvia C. Jogos de espelhos: imagens da representação de si através dos outros. São Paulo: Edusp, 1993.

PACHECO DE OLIVEIRA, João. Ensaios em Antropologia Histórica. Rio de Janeiro: UFRJ, 1999.

O antropólogo como perito: entre o indianismo e o indigenismo. In: L'ESTOILE, Benoit; NEIBURG, Frederico; SIGAUD, Lygia (Org). Antropologia, impérios e estados nacionais. Rio de Janeiro: Relume Dumará/FAPERJ, 2002. p. 253277.

PERES, Sidnei. SPI, etnicidade e indigenismo no Nordeste: cotidianidade e historicidade do poder tutelar. In: FREIRE, Carlos A. R.(Org.). Memória do SPI: textos, imagens e documentos sobre o Serviço de Proteção aos Índios (1910-1967). Rio de Janeiro: Museu do Índio/FUNAI, 2011.

PORTO ALEGRE, Maria Sylvia. Cultura e História: sobre o desaparecimento dos povos indígenas. Revista de Ciências Sociais, Fortaleza, v. 23/24, n. 1/2, p. 213-225, $1992 / 1993$.

Espaço Ameríndio, Porto Alegre, v. 7, n. 1, p. 37-94, jan./jun. 2013. 
VICTOR FERRI MAURO - Etnogênese e reelaboração da cultura entre os krahô-kanela...

_. "Rompendo o silêncio": por uma revisão do "desaparecimento dos povos indígenas". Ethnos, v. 2, n. 2, n./p. 1998. Disponível em: http://alagoasreal.blogspot.com.br/2012/02/rompendo-o-silencio-por-uma-revisaodo.html . Acesso em: 27 jun. 2013.

POUTIGNAT, Philippe; STREIFF-FENART, Jocelyne (Org.). Teorias da etnicidade. São Paulo: Editora da Unesp, 1988.

RAMOS, Alcida R. O índio hiper-real. Revista Brasileira de Ciências Sociais, São Paulo, v. 28, n. 10, p. 5-14, 1995. Disponível em: http://www.anpocs.org.br/portal/ publica coes/rbcs_00_28/rbcs28_01.htm. Acesso em: 18 ago 2011.

RIBAS, João B. C. O olhar. In: GUERRIERO, Silas (Org.). Antropos e psique: o outro e sua subjetividade. São Paulo: Olho D’água, 2002. p. 87-96.

RICARDO, Carlos A. Passados 500 anos, sequer sabemos seus nomes. In: GRUPIONI, Luís D. B.; VIDAL, Lux; FISCHMANN, Roseli (Org.). Povos indígenas e tolerância: construindo práticas de respeito e solidariedade. São Paulo: Edusp, 2001. p. 63-70.

SAHLINS, Marshall. O "pessimismo sentimental" e a experiência etnográfica: por que a cultura não é um "objeto" em via de extinção (parte II). Revista Mana, v. 3, n. 2, p. 103-150, 1997.

SAMPAIO, José A. L. O "resgate cultural" como valor: reflexões antropológicas sobre a formação de professores indígenas. In: GRUPIONI, Luís D. B. (Org.). Formação de professores indígenas: repensando trajetórias. Brasília: Ministério da Educação/Secretaria de Educação Continuada, Alfabetização e Diversidade, 2006. p. 165-174.

SCHWARCZ, Lilia M. O espetáculo das raças: cientistas, instituições e questão racial no Brasil - 1870-1930. São Paulo: Companhia das Letras, 1993.

O caleidoscópio da cultura. Revista de História da Biblioteca Nacional, Rio de Janeiro, v. 2, n. 18, p. 20, 2007.

SENADO FEDERAL. Secretaria de Taquigrafia. 16/06/2004. Disponível em: U:ISacei_Sscom_2004\Com_Esp_Ext_2003_2004\TerrasIndigenas\Notas_Taq 12004061 6.doc. Acesso em: 24 mai 2008.

TAUSSIG, Michel. Mimesis and Alterity: a particular history of the senses. New York: Routledge, 1993.

TAYLOR, Charles. Multiculturalismo: examinando a política de reconhecimento. Lisboa: Instituto Piaget, 1994.

TEÓFILO DA SILVA, Cristhian. Identificação étnica, territorialização e fronteiras: a perenidade das identidades indígenas como objeto de investigação antropológica e a 
VICTOR FERRI MAURO - Etnogênese e reelaboração da cultura entre os krahô-kanela...

ação indigenista. Revista de Estudos e Pesquisas, Brasília, v.2, n.1, p. 113-140, 2005.

TRIBO DOS KRAHÓ KANELA EXIBE SUA DANÇA DA SAÚDE E DA GENEROSIDADE. Portal de notícias Globo.com, 17/09/2010. Disponível em: http://g1.globo.com/globo-reporter/noticia/2010/09/tribo-dos-kraho-kanela-exibe-suadanca-da-saude-e-da-generosidade.html. Acesso em: 28 set 2012.

VIVEIROS DE CASTRO, Eduardo et al. Transformações indígenas: os regimes de subjetivação ameríndios à prova da história. Rio de Janeiro/Florianópolis: Projeto NUTI-Pronex, 2003.

No Brasil todo mundo é índio, exceto quem não é. In: RICARDO, Beto; RICARDO, Fany (Org.). Povos Indígenas no Brasil: 2001-2005. São Paulo: Instituto Socioambiental, 2006. p. 41-49.

WAGNER, Roy. A invenção da cultura. São Paulo: Cosacnaify, 2010. 